

\section{DISCLAIMER}

This report was prepared as an account of work sponsored by an agency of the United States Government. Neither the United States Government nor any agency Thereof, nor any of their employees, makes any warranty, express or implied, or assumes any legal liability or responsibility for the accuracy, completeness, or usefulness of any information, apparatus, product, or process disclosed, or represents that its use would not infringe privately owned rights. Reference herein to any specific commercial product, process, or service by trade name, trademark, manufacturer, or otherwise does not necessarily constitute or imply its endorsement, recommendation, or favoring by the United States Government or any agency thereof. The views and opinions of authors expressed herein do not necessarily state or reflect those of the United States Government or any agency thereof. 


\section{DISCLAIMER}

Portions of this document may be illegible in electronic image products. Images are produced from the best available original document. 


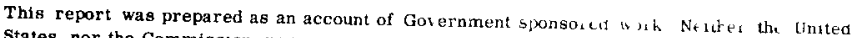
States, nor the Commission, nor anv person acting on be half of the combission

A Makes any warranty or represcntation, expressed or 1 mplit 1 with t copect

racy, completeness, or usefulness of the information cuntaund inc:

of any information, apparatus, method, or process dasc losed in this repret wa the privately owned rights, or

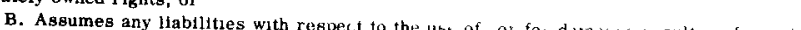
use of any information, dpparatus, method, or process disciosed in this reposting fictid the As used in the above "pera acting process disciosed in this report

ployee or contractor of the "person acting on behalf of the Commission" includes $q$ a $t$, such or contrartol to the iste $\mathbf{n}$ that disseminates, or providor of the Commission, or timplasee of such cuntractio prit ies with

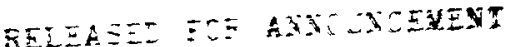

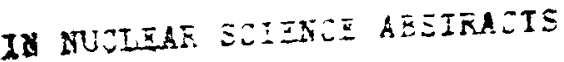

SC $-R R-66-589$

ROVER/PHOEBUS SCALED MODEL

CHEMICAL EXPLOSIVE DESTRUCT TEST RESULTS

R. E. Berry, 9312

Sandia Laboratory, Albuquerque

December 1966

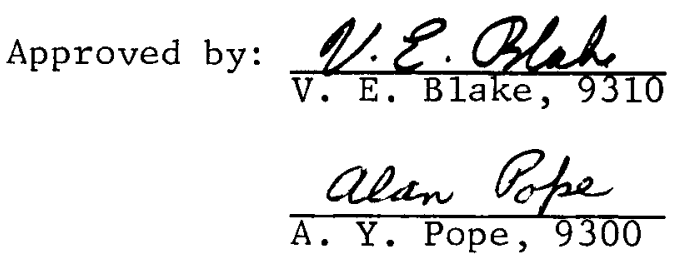

ABSTRACT

The ROVER/PHOEBUS scaled model tests were performed in partial fulfillment of Sandia Corporation's responsibility to evaluate the safety aspects of nuclear power supplies being proposed for space application.

Three tests were performed to provide base level or comparative data about the destruct event under controlled conditions. Data about the debris cloud shape, metallic parts distribution, and graphite particle size distribution were collected from these tests.

Future testing to determine the effects of nonsimultaneous firing of the explosive charges, varying the explosive entry angle into the core, and destroying the model with the core heated to near reactor operating temperature were delayed pending a redirection of the program when the results from the control tests indicated that with the present explosive weight, perturbations would not be observable. During the delay period, the explosive destruct mode of disposal became less attractive, and the test program was canceled. 


\section{ACKNOWLEDGMENT}

The author wishes to express appreciation to all divisions and individuals who were instrumental in the performance of the destruct testing and the reduction and evaluation of the test data.

Special appreciation is extended to:

R. D. Jones, 7336

J. P. Martin, 9232

H. J. P1agge, 7343

R. R. Middlesworth, 9312

Chemica1 Engineering Department,

University of New Mexico

for their contributions to test preparation and inputs to this report.

Issued by Sandia Corporation

a prime contractor to the

United States Atomic Energy Commission

\section{LE G A L NOTICE}

This report was prepared as an account of Government sponsored work, Ne1ther the United States, nor the Commission, nor any person acting on behalf of the Commission.

A. Makes any warranty or representation, expressed or implied, with respect to the accuracy, completeness, or usefulness of the information contained in this report, or that the use of any information, apparatus, method, or process disclosed in this report may not infringe privately owned rights, or

B. Assumes any liabilities w1th respect to the use of, or for damages resulting from the use of any information, apparatus, method, or process disclosed in this report.

As used in the above, "person acting on behalf of the Commission" includes any employee or contractor of the Commission, or employee of such contractor, to the extent that such employee or contractor of the Commission, or employee of such contractor prepares, disseminates, or provides access to, any information pursuant to his employment or contract with the Commission, or his employment with such contractor. 


\section{SUMMARY}

The scaled-model tests were performed to provide base-line data which were to be compared with data obtained from testing in which specified perturbations were introduced. The perturbations were: (1) varying the entry angle of the explosive charge, i.e., changing the explosive charge angle across a quadrant of the core from 45 degrees to a smaller angle and then to a larger angle; (2) varying the simultaneity of firing the four explosive charges, and (3) destroying the test vessel with the core heated to near reactor operating temperature.

The tests to determine the effects of the perturbations were initially delayed because the debris pattern observed in the control tests indicated that the perturbations in (1) and (2) would not be observable, and the temperature required in (3) to affect the breakup characteristics of the graphite core was not feasible without cooling the metal case components.

Later in the program, the entire explosive destruct technique became less attractive, and all future testing was canceled.

Three control tests were performed; two used four scaled 120-mm explosive charges, and one used four scaled 155-mm explosive charges. Al1 tests were performed with the charges emplaced across each core quadrant. In all three tests, there was a decided lack of the jetting which was observed in previous tests using charges paralle1 to the core axis.

The atmospheric shock overpressures observed were 15 psi at 8 feet, dropping to 1 psi at 40 feet when using scaled $120-\mathrm{mm}$ explosive charges. The overpressure was 35 psi at 8 feet, dropping to 2 psi at 40 feet when using scaled 155-mm explosive charges.

The shock-wave velocity within the core was measured at 0.11 inch per microsecond, which compares favorably with a literature value of 0.18 inch per microsecond for a TNT/carbon system. The detonator firing simultaneity had a maximum spread of 0.2 microsecond for all three tests.

The metallic debris and the graphite core debris were in larger sizes, indicating that a straight volume scale-up is insufficient to produce comparable breakup in the larger test vessel. Both the NERVA and PHOEBUS models were $1 / 6$ scale, and the explosive charges used, $105 \mathrm{~mm}$ scaled for NERVA and $155 \mathrm{~mm}$ scaled for PHOEBUS, had the same core-volume to explosive-volume ratio, but the debris sizes were quite different.

Jetting does not occur with the charges emplaced across each quadrant in the PHOEBUS model. However, additional information is needed to determine whether the lack of jetting was caused by a larger volume core or by the placement of charges. 
The performance of PHOEBUS scaled-model tests using scaled $120-\mathrm{mm}$ and $155-\mathrm{mm}$ explosive charges emplaced parallel to the core axis is recommended. This parallel charge debris pattern information would establish the reason for no jetting; increased volume or charge placement. 
Introduction . . . . . . . . . . . . . . . . . 9 9

Purpose of Tests . . . . . . . . . . . . . . . 9

Test Setup . . . . . . . . . . . . . . . . . 10

Description of Instrumentation . . . . . . . . . . . . 10

Photographic . . . . . . . . . . . . . 12

Case Rupture .. . . . . . . . . . . . . 12

Detonator Fire .. . . . . . . . . . . . . 14

Shock-Wave Velocity . . . . . . . . . . . . . 14

Atmospheric Shock Transducer . . . . . . . . . . 14

Description of Test Vesse1 . . . . . . . . . . . . 15

Description of Explosive . . . . . . . . . . . . . . 16

Arming and Firing System . . . . . . . . . . . . . . 16

Requirements . . . . . . . . . . . . . . 16

Firing System.................... 17

Safety Procedures .. . . . . . . . . . . . 19

Arming and Firing Procedure . . . . . . . . . . 20

Data Collection . . . . . . . . . . . . . . 21

Test Results . . . . . . . . . . . . . . . . . 22

Pin Switches .. . . . . . . . . . . . 22

Crysta1 Shock-Wave Velocity Gages . . . . . . . . . 22

Atmospheric Shock Overpressure Gages . . . . . . . . . 23

Case Rupture Instruments . . . . . . . . . . . 24

Metallic Debris Distribution . . . . . . . . . 25

Graphite Debris Recovery . . . . . . . . . . . . . 31

Graphite Debris Distribution . . . . . . . . . 31

Conclusions and Recommendations . . . . . . . . . . . 31

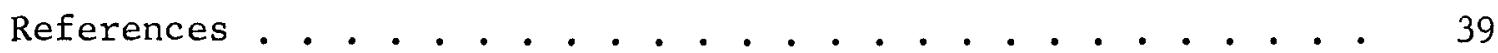

APPENDIX A - ROVER/PHOEBUS Scale-Model Test Program . . . . 41 


\section{LIST OF ILLUSTRATIONS}

$\underline{\text { Figure }}$

$\underline{\text { Page }}$

1. ROVER/PHOEBUS scaled-model test site . . . . . . . . . 11

2. Diagram of ROVER/PHOEBUS test site . . . . . . . . 11

3. Case rupture instrumentation . . . . . . . . . . . . 13

4. Case break electrical schematic . . . . . . . . . . 14

5. Inner cylinder and core support plate enclosing graphite core . . . . . . . . . . . . . . . . 15

6. Outer case with simulated reflector rings and control drums installed . . . . . . . . . . . . . 15

7. Assembled PHOEBUS test vessel . . . . . . . . . 15

8. Test vessel with dome and plastic ring removed . . . . 15

9. Simulated reflector ring and control drums . . . . . 16

10. Dome with plastic installed and plastic ring . . . . . 16

11. TC-2 power supply, field test X-unit, and junction box... . . . . . . . . . . . . . . . 17

12. Junction box schematic . . . . . . . . . . . 18

13. Control panel schematic . . . . . . . . . . 19

14. ROVER/PHOEBUS Test 1 metallic fragments distribution . 26

15. ROVER/PHOEBUS Test 2 metallic fragments distribution . 27

16. ROVER/PHOEBUS Test 3 metallic fragments distribution . 28

17. ROVER/NERVA scaled-model debris distribution . . . . 29

18. ROVER/NERVA ful1-scale debris distribution . . . . . 30

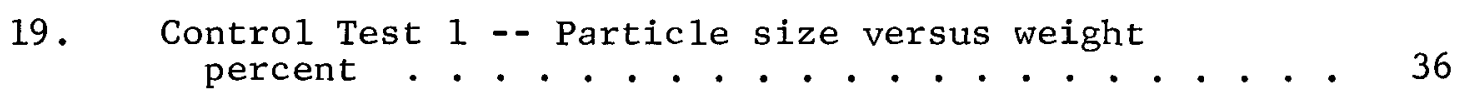

20. Control Test 2 -- Particle size versus weight

21. Control Test 3 -- Particle size versus weight

22. Control Test 1 -- Particle size versus accumulated

23. Control Test 2 -- Particle size versus accumulated 37

24. Control Test 3 -- Particle size versus accumulated 37

25. Control test comparison -- particle size versus 38

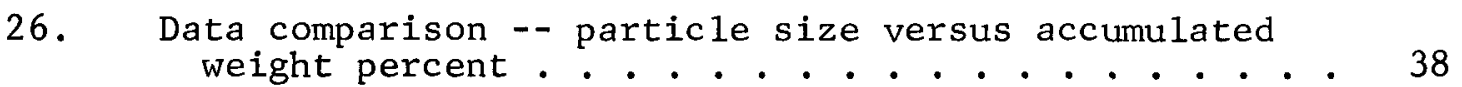




\section{LIST OF TABLES}

Table $\quad \underline{\text { Page }}$

I. Pin Switches - Detonator Fire . . . . . . . . 22

II. Crystal Shock Wave Velocity Gages . . . . . . . 22

III. Calculated Velocities for the TNT/Graphite Core . . 23

IV. Atmospheric Shock Overpressure Measurements . . . 23

V. NERVA Scaled Model and Full Scale Overpressure Measurements . . . . . . . . . . . 24

VI. Case Rupture Data for ROVER/PHOEBUS Tests 1 and 2 . 24

VII. Case Rupture Data for ROVER/PHOEBUS Test 3 . . . . 25

VIII. Graphite Recovery . . . . . . . . . . . . 31

IX. Graphite Debris Distribution for Test 1 . . . . 33

X. Graphite Debris Distribution for Test 2 . . . . . 34

XI. Graphite Debris Distribution for Test 3 . . . . 35 
Blank Page 


\title{
ROVER/PHOEBUS SCALED MODEL CHEMICAL EXPLOSIVE DESTRUCT TEST RESULTS
}

\author{
Introduction
}

The Atomic Energy Commission assigned to Sandia Corporation the responsibility of making independent safety analyses of a11 nuclear power supplies which are designed for space application. In partial fulfillment of this responsibility, debris distribution data were collected from scaled-model propulsion engine destruct tests. These data will assist in the safety evaluation of space disposal of radioactive debris which results from the destruction in space of a nuclear propulsion engine.

Data for evaluation of the space engine use were collected from scaled-model ROVER/NERVA test vessels and from a ful1-scale test at Aberdeen Proving Ground. This collection of data is a continuing effort to provide an acceptable safety criteria for the ROVER nuclear propulsion engine. Scaled-model ROVER/PHOEBUS tests were initiated to provide additional information about the destruct event when the four charges are fired nonsimultaneously, when the charge entry angle is varied from the nominal, and when the core is heated to near reactor operating temperature.

An outline of the tests planned for this test series is included in Appendix A. However, when testing was initiated, the anticipated dispersion and breakup did not occur, the necessary data could not be obtained, and a reorientation of the test program was necessary. Originally, twelve tests were planned, but only three tests were completed; the remaining tests were canceled.

\section{Purpose of Tests}

These tests were performed to provide additional data for safety assessment of a nuclear propulsion engine when used in space. Previous testing of a similar system is reported in thpee unclassified documents.1, 0 These previous tests were performed using a ROVER/ NERVA scaled-model propulsion engine, and the chemical explosive charges were statically emplaced parallel to the longitudinal axis of the test vessel. 
The tests in this series were performed using a ROVER/PHOEBUS scaled-model propulsion engine, and the chemical explosive charges were statically emplaced diagonally across each quadrant of the reactor core. A more detailed description of the test vessel is contained in a following section.

A complete test plan is contained in Appendix A. However, a brief description of the program follows. Basically, three areas were to be investigated:

1. The effects of varying the entry angle of the explosive charge,

2. The effects of firing the four charges in a nonsimultaneous pattern, and

3. The effects of firing the explosive charges with the graphite core heated to near reactor operating temperature.

To establish a base line for comparison of the test results obtained in the above, a series of tests were performed under controlled destruct conditions. Ideally, these data from the base-1ine tests would establish the particle size and velocity, pressure vessel breakup and distribution, and the presence of any jetting or other unique phenomenon. Variation created by perturbing the test conditions would then be evident when compared to this base-line data.

\section{Test Setup}

The test setup for these tests consisted of a concrete hemisphere, 16 feet in diameter, sunk into the ground. Two telephone poles placed adjacent to the hemispherical hole supported a camera platform 50 feet above ground leve1 (Figure 1). Since these tests were performed to establish the debris pattern, a multiple camera installation was used to provide data from three orthogonal directions (Figure 2).

\section{Description of Instrumentation}

PHOEBUS scaled-model tests were performed to establish the debris distribution pattern when skewed charges were used for the destruct event. In addition to the primary objective stated above, instrumentation was provided to establish the atmospheric shock overpressure versus distance, the time of detonator fire, the shockwave velocity occurring within the simulated core, and the times of inner cylinder-break and outer case break. 


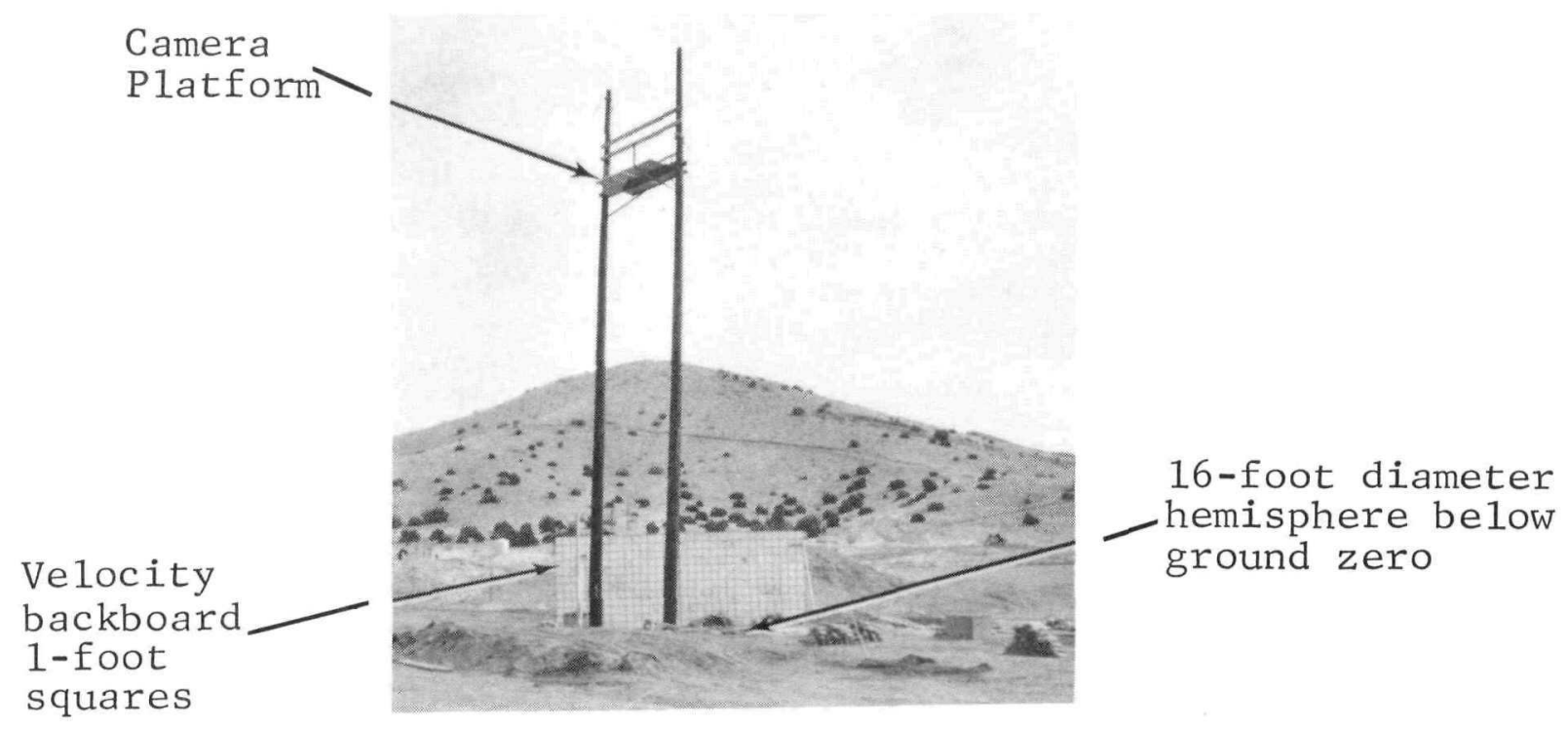

Figure 1. ROVER/PHOEBUS scaled-mode1 test site

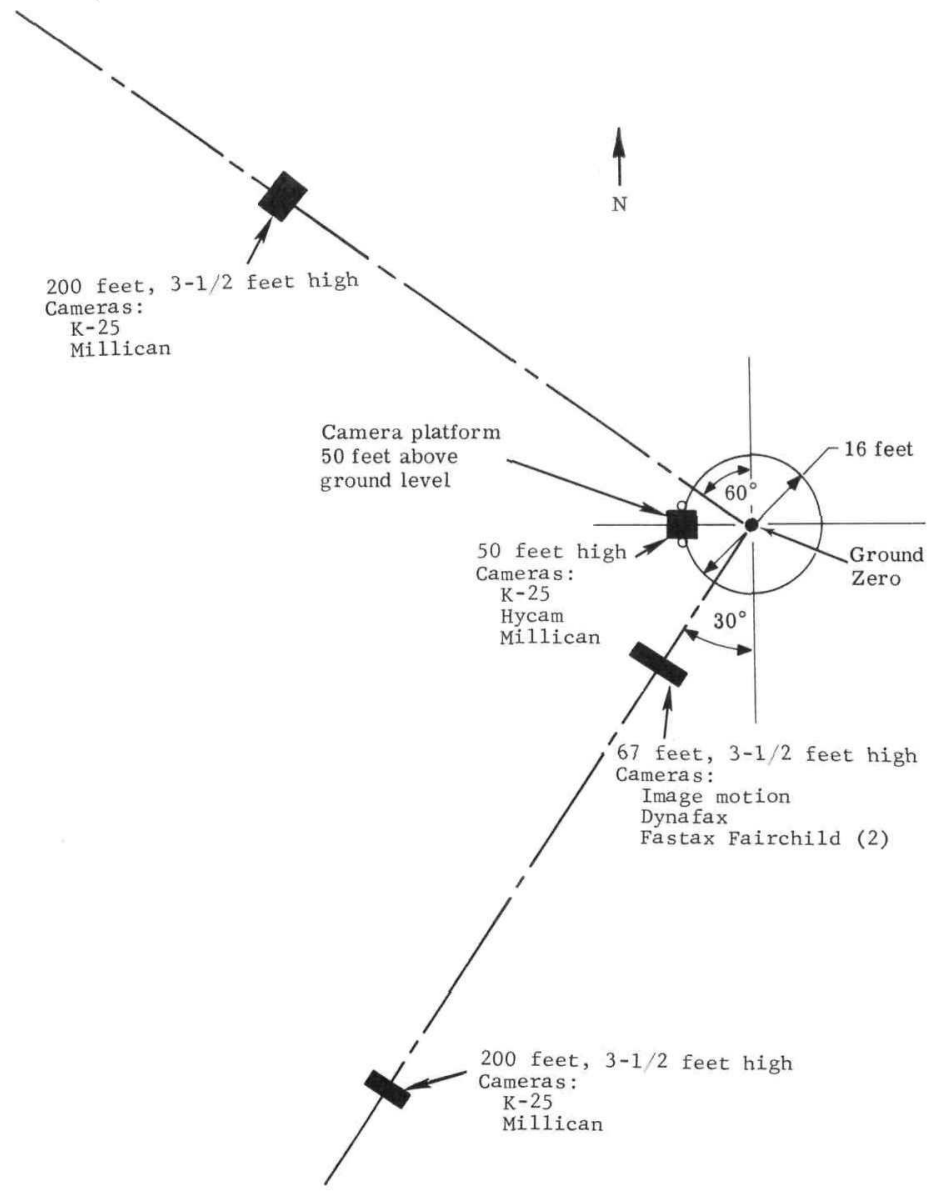

Figure 2. Diagram of ROVER/PHOEBUS test site 
The camera film contained timing marks and provided 90-degree coverage as well as overhead coverage. A high-speed streak camera monitored externa1 detonator firing and case rupture. The atmospheric shock transducers measured pressure from near ground zero along a single line to a distance of about 40 feet. The pin switches were installed adjacent to the four internal detonators and monitored detonator firing time. Crystal transducers were installed in the simulated core and monitored shock-wave travel through the graphite material. Case breakup was monitored by conductive strips around the inner cylinder and the outer case. The pin switches, crystal transducers, shock transducers, and case break strips were referenced to a zero time signal such that the time from fire signal to transducer function was known. The test vessels were suspended 5 feet above ground over the "swimming pool" facility. The above mentioned data collection techniques are described in the following sections.

\section{Photographic}

Film coverage of the destruct event documented the distribution of debris from four locations: (1) close to ground zero (about 67 feet); (2) remote from ground zero (GZ) along the same radial line as (1) (about 200 feet); (3) remote from ground zero along a line 90 degrees from the previous locations (about 200 feet); (4) overhead from ground zero (about 50 feet above and 8 feet from GZ).

Cameras used for the coverage were slow speed to monitor debris cloud movement, medium speed for overal1 documentation of the event, high speed for case component velocity measurements, and extra high speed to monitor detonator fire and case rupture.

\section{Case Rupture}

To determine the time interval from detonation to case rupture, a ring of electrically conductive paint approximately 0.5 inch wide was brushed over insulating tape which was wrapped around the outside of the aluminum test vesse1 and around the inner aluminum core retainer wall. The tape was placed in two positions on the aluminum cases; one near the top, the other near the lower end (Figure 3). A conductive paint was used for this application in an effort to minimize the amount of stretch which the sensor would undergo before breaking. Various types of wire were tested, but each exhibited an unacceptable amount of stretch before breaking.

Each sensor was integrated with the circuit shown in Figure 4. The sensors were connected across the $15 \mathrm{~K}$ resistors. When the test vesse1 case ruptured and broke the conductive paths provided by the paint, the electrical shorts were removed from the $15 \mathrm{~K}$ resistors; this resulted in a change in the input voltages to the voltagecontrolled oscillators. These changes in voltage resulted in a change in the frequency of the output signals of the voltage-controlled oscillators. The output signals from the oscillators and the fiducial signal which indicated the time of detonation of the four explosive charges in the test vessel were recorded on magnetic tape. 


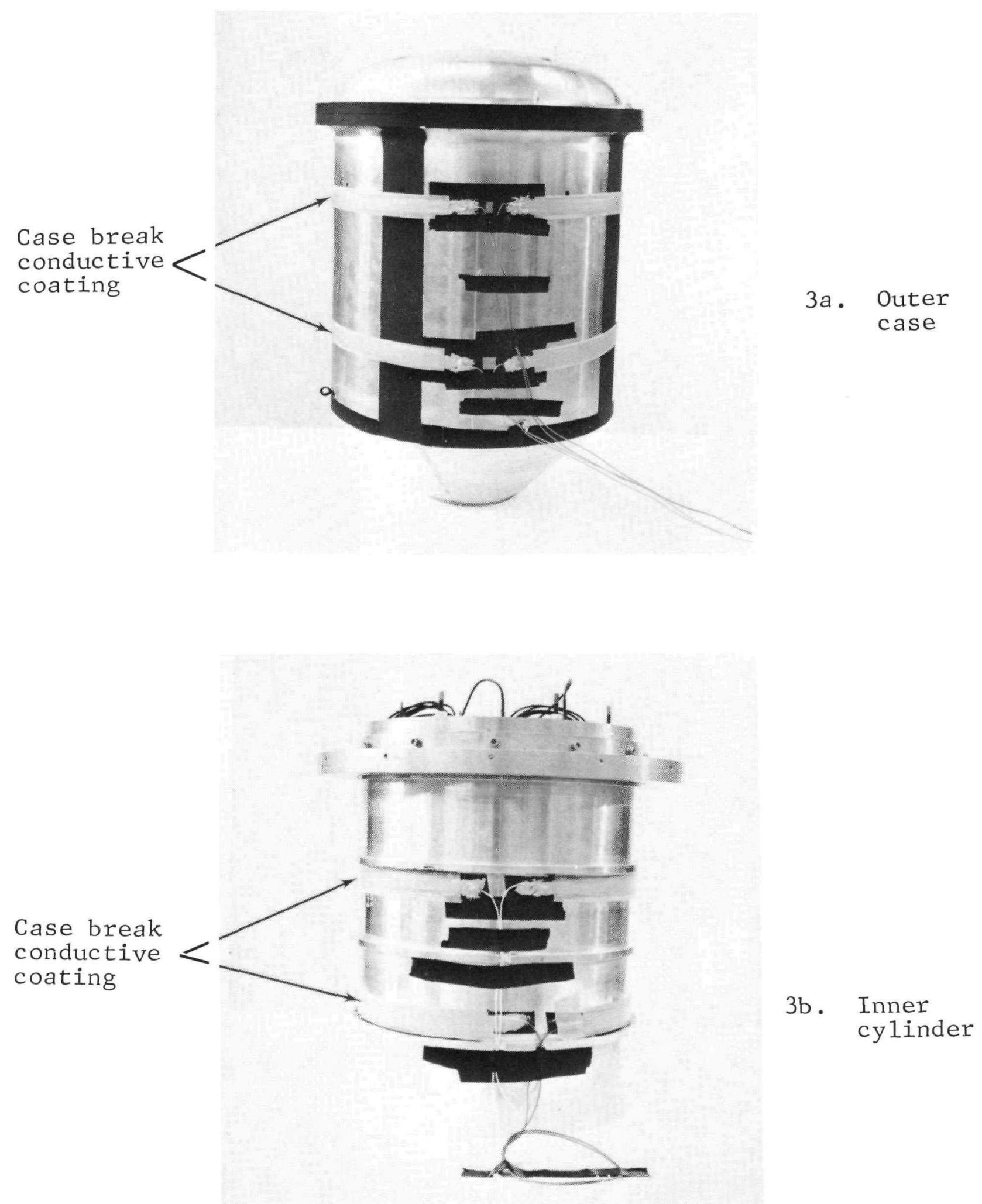

Figure 3. Case rupture instrumentation 


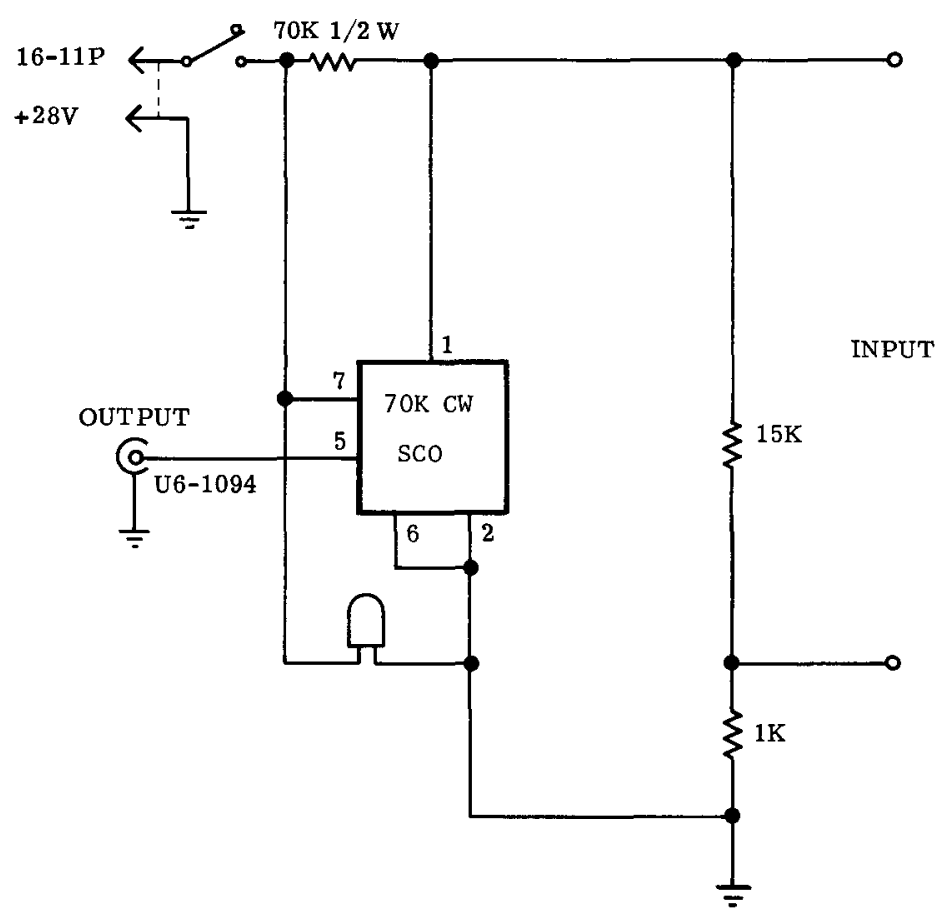

Figure 4. Case break electrical schematic

\section{Detonator Fire}

The simultaneity of firing of the four SE-1 detonators was monitored by four pin switches. The pin switches were produced by Channel Industries, and the output was fed into an Erco Squaring Circuit Module. This signal was recorded on an Ampex FR1400 magnetic tape recorder.

\section{Shock-Wave Velocity}

The shock-wave velocity within the core was measured at four locations, using Channel Industries crystal shock-wave transducers. The signal from the transducers was fed into an Erco amplifier and recorded on an Ampex FR1400 magnetic tape recorder.

\section{Atmospheric Shock Transducer}

The atmospheric shock transducers used were Susquehana ST-2 pressure transducers working with Endevco charge amplifiers. The output from the amplifier was recorded on an Ampex FR1400 magnetic tape recorder. 


\section{Description of Test Vesse1}

Scaled-model test vesse1s used for these tests are completely described on Sandia Drawing No. N-99888. These models simulate the actual propulsion engine as closely as possible in those areas considered to be important to the debris distribution resulting from explosive destruct. The major items were scaled directly, and weights equal to the smal1 items' weights were included in the larger structures where feasible. The only part which was not scaled was the size and shape of the fuel element. The overall core was scaled using full-size fuel elements as the building blocks. Figures 5 through 10 show various views of the test vehicle.

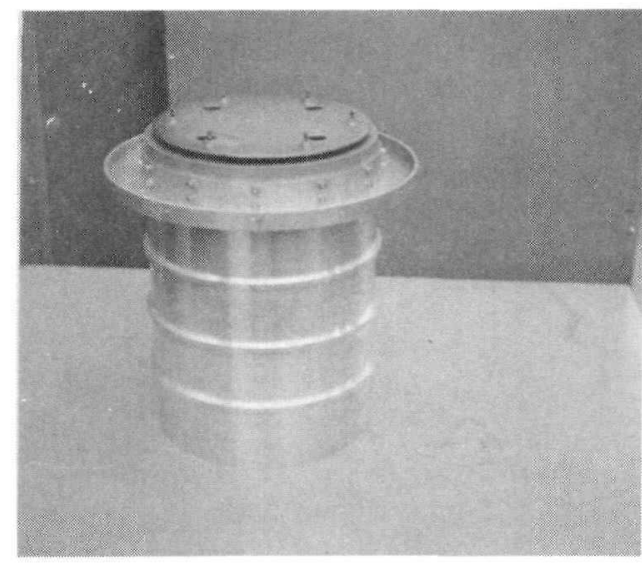

Figure 5. Inner cylinder and core support plate enclosing graphite core

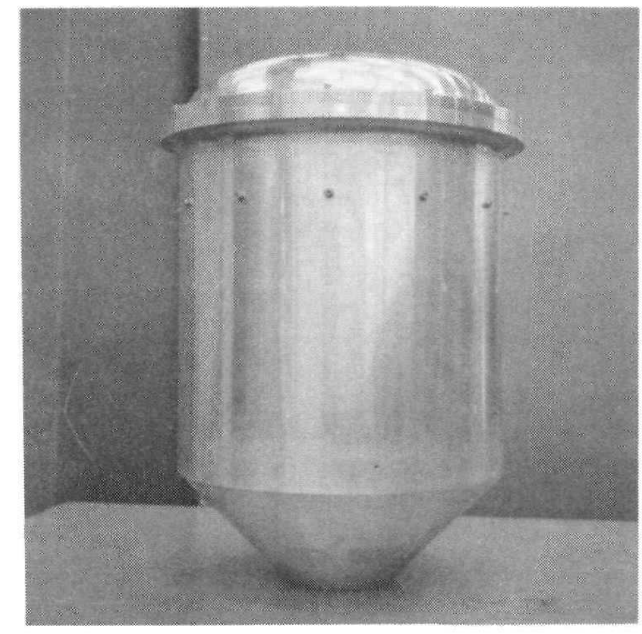

Figure 7. Assembled PHOEBUS test vesse 1

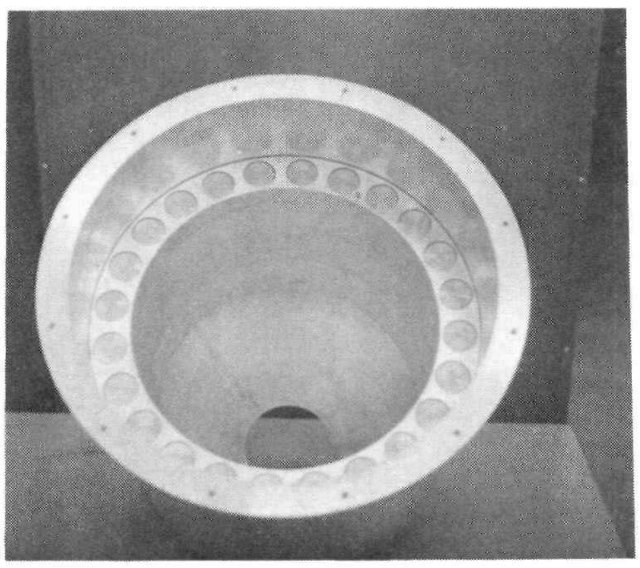

Figure 6. Outer case with simulated reflector rings and contro1 drums installed

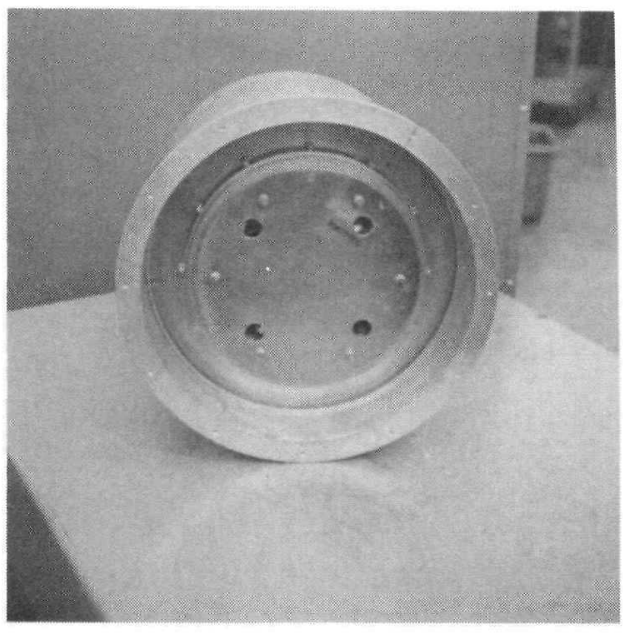

Figure 8. Test vessel with dome and plastic ring removed 


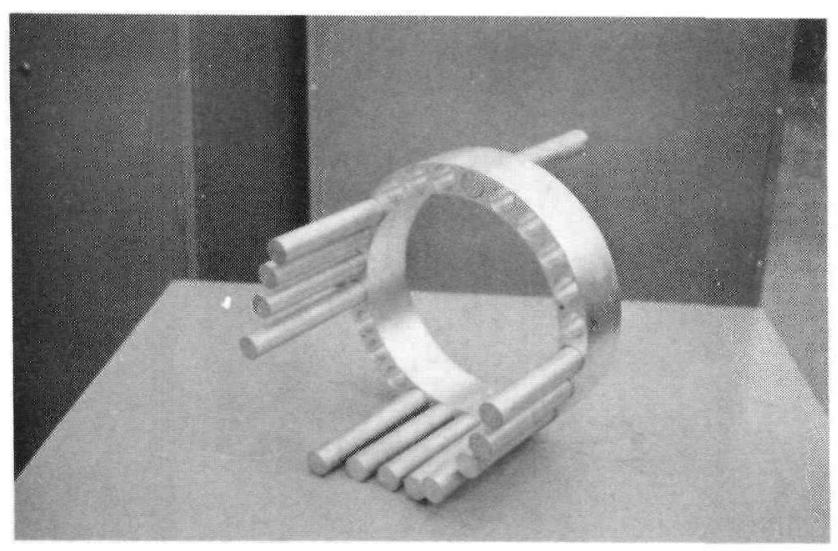

Figure 9. Simulated reflector ring and control drums

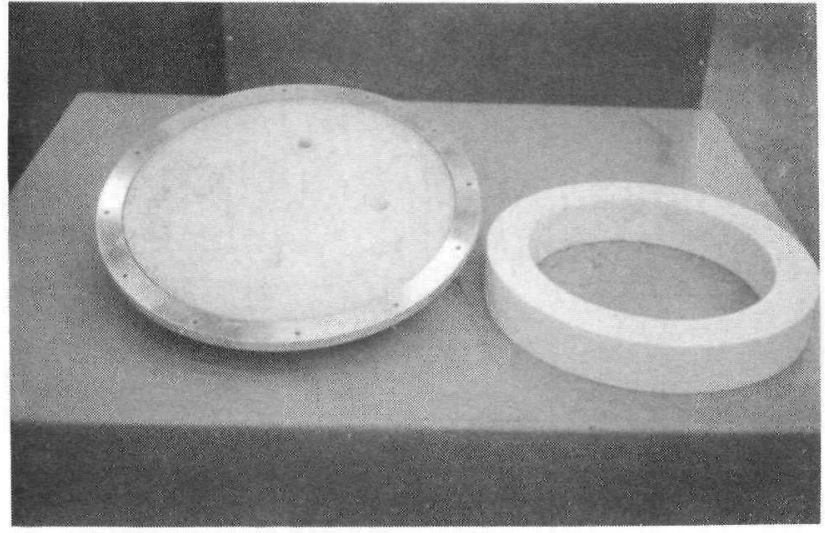

Figure 10. Dome with plastic

insta1led and

plastic ring

\section{Description of Explosive}

The simulated propulsion engine was destroyed by four explosive charges which were individually initiated by an exploding bridgewire detonator. The explosive charges used for the first two tests were scaled $120-\mathrm{mm}$ projectiles and consisted of 75.5 grams of TNT in each of the four charges, for a total weight of 302 grams. The explosive charges used for the third test were scaled 155-mm projectiles and consisted of 114 grams of TNT in each of the four charges, for a total weight of 456 grams. The three tests were initiated using SE-1 detonators and tetryl booster pellets. The SE-1 explosive charge consists of 250 milligrams of PETN and 375 milligrams of PBX. The booster pellet is $1 / 2$ inch in diameter of $1 / 2$-inch high. The explosive train was initiated according to the requirements and procedures described in the section on "Arming and Firing."

\section{Arming and Firing System}

\section{Requirements}

The arming and firing system must provide maximum safety and must provide a precise time of firing as well as simultaneous firing of all detonators. The detonators shall be initiated and fired within 5 microseconds after the firing pulse occurs. The equipment and procedures used to accomplish this are described in the following paragraphs . 


\section{Firing System}

The arming and firing system components, in conjunction with the camera control countdown generator, provided maximum safety and also ensured that the cameras were started at the proper times. The countdown generator provided a switch closure for firing the explosive charges. From minus 10 seconds on, all camera activities and firing were controlled by the countdown generator.

The firing system was assembled from the following components:

$$
\begin{aligned}
& \text { TC-2 high-voltage supply } \\
& \text { FTXU - field test X-unit } \\
& \text { Junction box } \\
& \text { Contro1 pane1 } \\
& \text { Associated cables }
\end{aligned}
$$

The TC-2 high-voltage supply is a dual-voltage device; it receives a 28-volt input from nicke1-cadmium batteries and transforms the voltage to 2500 volts which are used to charge the capacitor of the FTXU. Interlock relays, set to close at 2400 volts, provide a 28 -volt return signal which indicates full voltage available (Figure 11).

The FTXU (Figure 11) is a single capacitor device with a dua1trigger circuit; either channel will dump full voltage (2500 volts) through the 16 output connectors. The pulse through the 16 output connectors lasts 3-1/2 microseconds (positive phase) and has a rise time such that the total scatter in voltage application to a11 16 output connectors does not exceed 60 nanoseconds ( $6 \times 10^{-8}$ second).

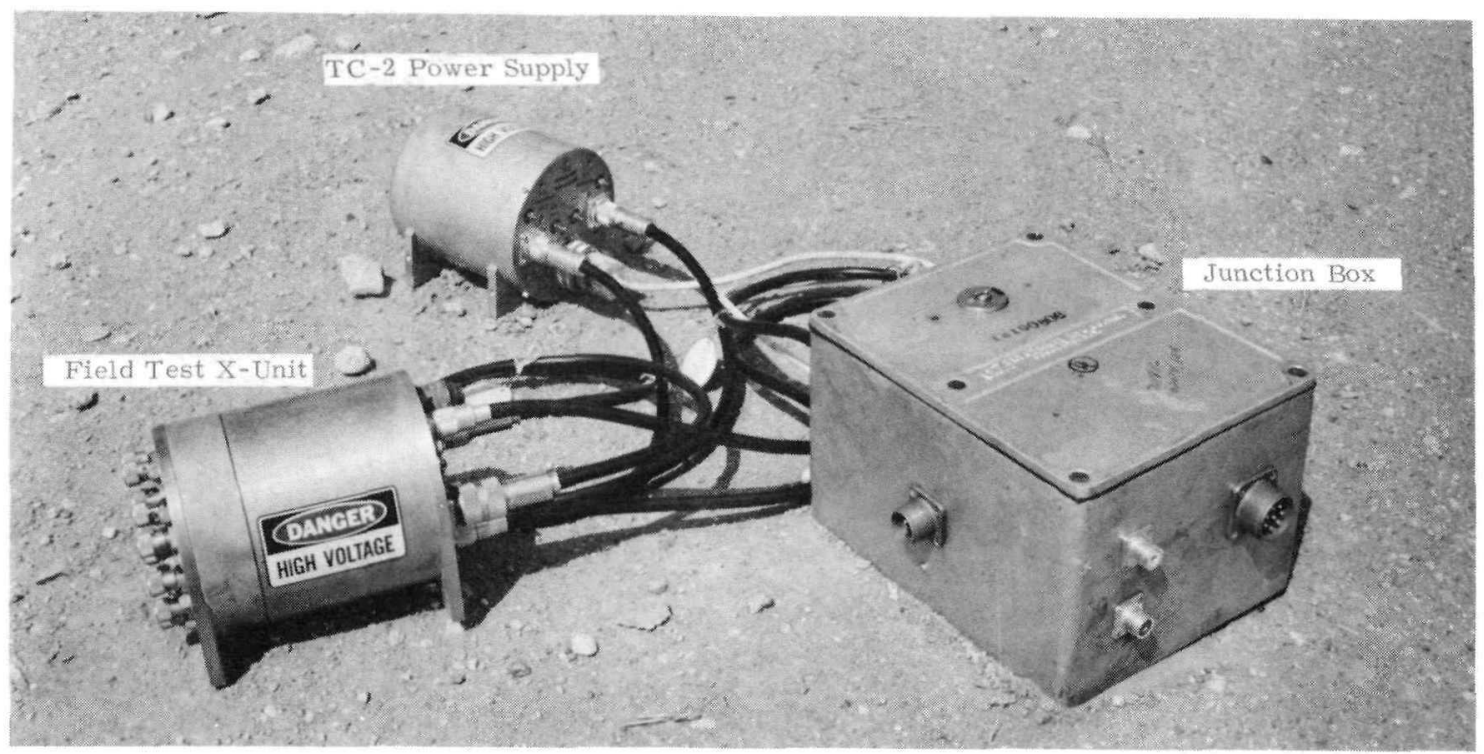

Figure 11. TC-2 power supply, field test X-unit, and junction box 
The junction box (Figure 11) provides the termination for control cables, power supply, and X-unit. The junction box is provided with a "keyed" shorting switch which prevents premature firing at the time of final detonator cable connection. Figure 12 is a schematic diagram of the junction box circuit.

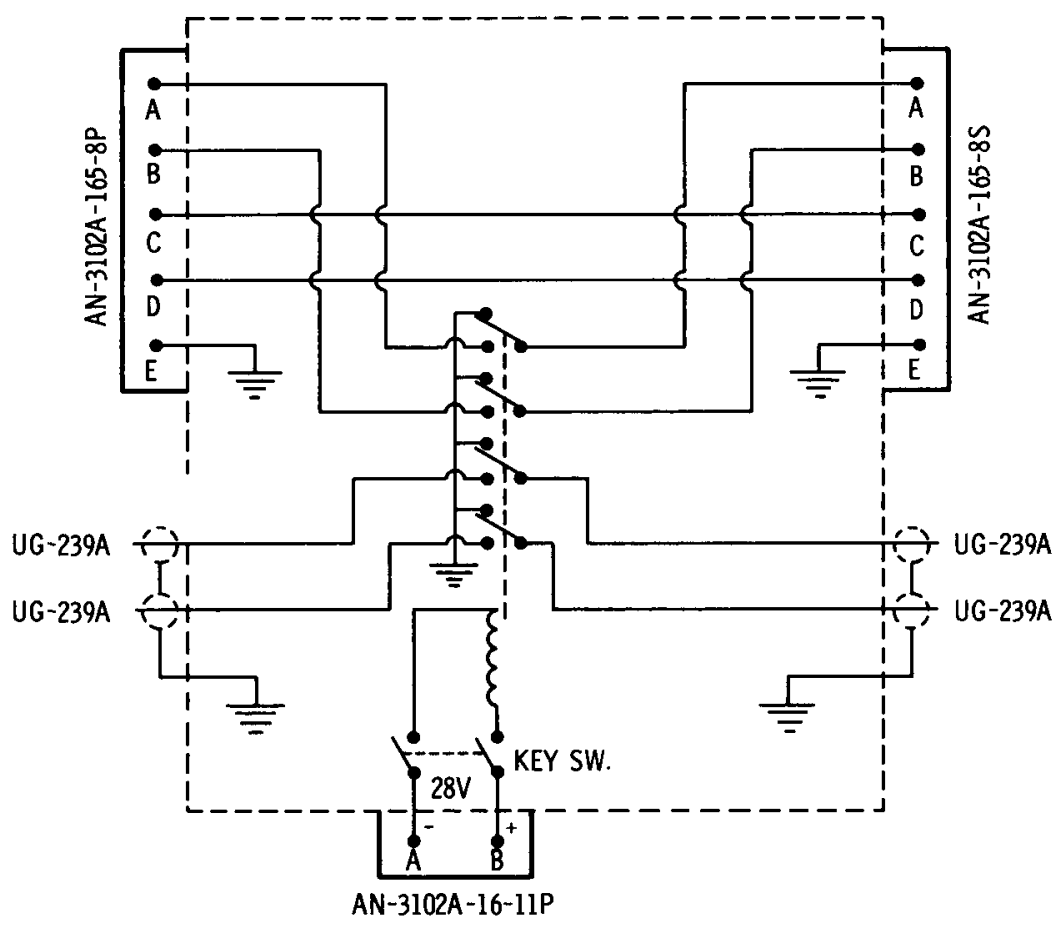

Figure 12. Junction box schematic

The control pane1, which is located in the control center, initiates charging and firing of the X-unit. This control panel is also provided with a "keyed" shorting switch which grounds al1 firing and charging circuits. Figure 13 is a schematic of the control panel electrical circuit.

One key, which is in the possession of the Arming Officer at al1 times, provides access to both the junction box and the control pane1. Figure 11 shows the firing system components interconnected. 


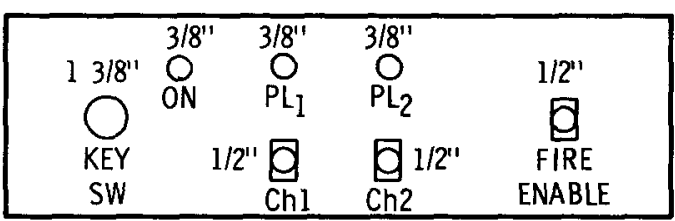

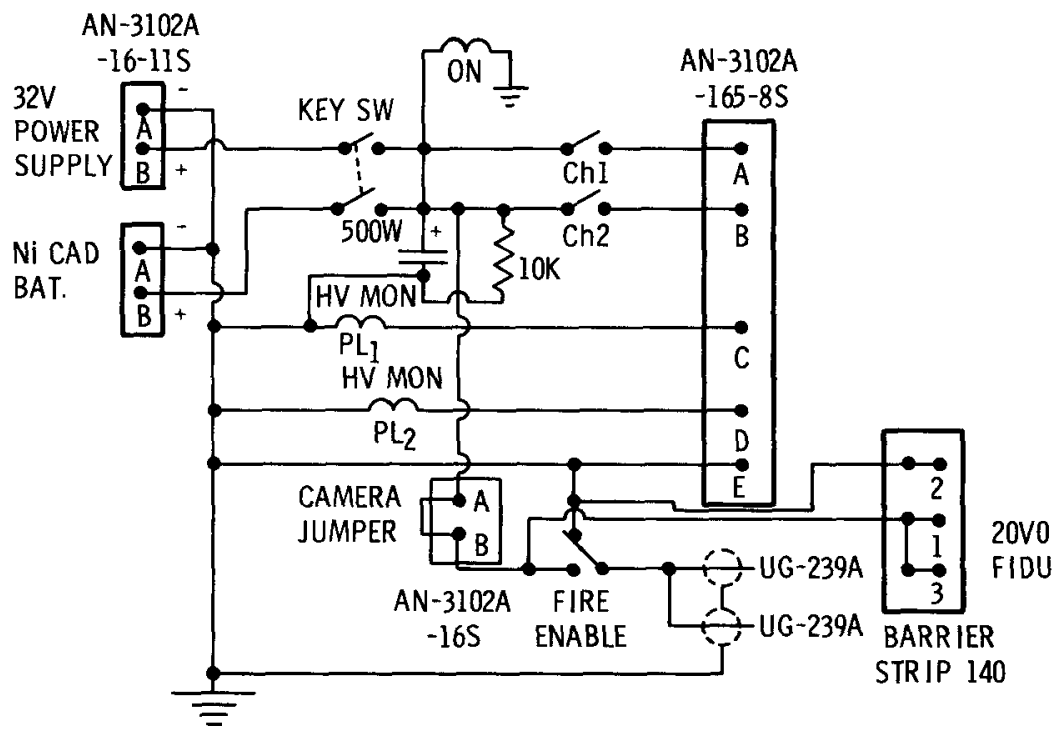

Figure 13. Control pane1 schematic

\section{Safety Procedures}

The following procedures were observed in order to provide maximum protection against accidental firing.

1. The minimum arming and firing crew consisted of two people.

2. The single junction box and control panel key was in the possession of the Arming Officer at all times, and the switches on both control units were in the "shorted" position.

3. The atmospheric potential gradient was at al1 times below the 400 volts maximum.

4. The firing system and the detonators were approved high-energy devices, properly certified to be of high quality. 


\section{Arming and Firing Procedure}

The following arming and firing procedure was followed.

1. Prior to the final arming (connecting detonators

to the X-units), the following checks were made:

a. Control pane1 key switch OFF and key removed.

b. Junction box key switch OFF and key removed.

c. Shorting plugs in place on X-unit end of detonator cables.

d. No voltage present at X-unit detonator cable connectors (checked with a VOM having 20,000 ohms per volt).

e. A11 interconnecting cables in place and firmly attached to the junction box, the TC-2 high-voltage supply, and the X-unit.

2. The following arming procedure was followed:

a. The shorting plug was removed from a detonator cable. The cable and detonator were tested, with test set $T-27$, for a cable plus detonator resistance of $0.375 \pm 0.005 \mathrm{ohm}$. (No other test set may be safely used.) Resistance values significantly varying from the above value would indicate a faulty detonator and/or cable. The cable was connected to the X-unit by means of one of the outer ring connectors. The procedure was repeated for each cable in turn.

b. Upon completion of Step a, the key was inserted to turn ON the junction box. The key was removed. Operation of the relay inside the box was audible to the operator. This step removed the ground connection from the trigger cable and the TC-2 voltage supply cables and connected them to the main cables leading to the contro1 pane1.

c. Arming was now complete, and the arming party returned to the control point.

3. The following fire enabling procedure was used:

a. The key was inserted in the control pane1 key switch and turned $\mathrm{ON}$. Lighting of an amber pilot lamp indicated POWER ON. 
b. The FIRE ENABLE switch was in the down (OFF) position, and the safety cover was closed.

c. Safety covers were lifted above the Charge 1 and Charge 2 switches on the control panel, and the switches were turned to ON. After a short delay, the red pilot lamps over the switches indicated that the TC-2 power supply had charged the X-unit capacitor to within 100 volts of the final charge voltage.

d. When both the Charge 1 and Charge 2 pilot lamps were properly 1it, the unit was ready for firing. The FIRE ENABLE switch was set to the ON position at about T-1 minute during the countdown.

4. The firing and the follow-up procedures were as follows:

a. The actual firing was accomplished by a switch closure in the camera control countdown generator. At the instant this switch closed, a 28volt signa1 was applied to both trigger cables leading to the $\mathrm{X}$-unit and to other devices requiring a signal at zero time.

b. After the firing, the Arming Officer turned the control panel key switch to OFF, removed the key, and proceeded to ground zero and inserted the key in the junction box key switch and turned it to OFF.

\section{Data Collection}

The primary purpose of these tests was to establish the debris pattern and distribution. Therefore, instrumentation which would have interfered with the photographic instrumentation was kept to a minimum. Twelve cameras were used in three orthogonal locations to establish the shape of the debris cloud resulting from the explosion. Other instrumentation included pin switches, crystal shock-wave velocity gages, atmospheric shock overpressure gages, and case break gages. The output from these gages was recorded on magnetic tape. Pin switches established the time delay from triggering to detonator fire and also determined the simultaneity of detonator firing. Crysta1 shock-wave velocity gages measured the attenuation of the shock wave through the graphite core material. Atmospheric shock overpressure gages established the external overpressure from the destruct event as a function of the distance from ground zero. Case break gages established the time from triggering to inner cylinder rupture at top and bottom, and from triggering to outer case rupture at top and bottom. 
It was not intended to collect graphite debris from these tests because the dispersion was expected to exceed the hard surface area. However, the actual debris dispersion allowed graphite collection and subsequent determination of particle size and distribution data.

\section{Test Results}

A11 instrumentation functioned satisfactorily on these tests. Data were collected from each instrument in the three tests, and these data show very good repeatability between tests.

\section{Pin Switches}

The results of the pin-switch measurements are given in Table $I$.

TABLE I

Pin Switches--Detonator Fire

Microseconds from Triggering

Control Test 1 Contro1 Test 2 Control Test 3

$\begin{array}{llll}\text { Detonator } 1 & 3.7 & 3.4 & 3.2 \\ \text { Detonator } 2 & 3.5 & 3.3 & 3.25 \\ \text { Detonator } 3 & 3.5 & 3.4 & 3.1 \\ \text { Detonator } 4 & 3.6 & 3.5 & 3.25\end{array}$

\section{Crysta1 Shock-Wave Velocity Gages}

The results of the shock-wave velocity gage measurements are given in Table II.

TABLE II

Crysta1 Shock-Wave Velocity Gages

Microseconds from Triggering

\begin{tabular}{lcccc} 
& \multicolumn{1}{c}{ Contro1 Test 1 } & Control Test 2 & Contro1 Test 3 \\
\cline { 2 - 2 } Transducer A & 49 & 46 & 47 \\
Transducer B & 45 & 49 & 35 \\
Transducer C & 47 & 42 & 46 \\
Transducer D & 36 & 48 & 48
\end{tabular}


Shock-wave velocity obtained from a literature source indicates about 0.18 inch per microsecond for a TNT/carbon system. The calculated velocities for the TNT/graphite core are given in Table III.

\section{TABLE III}

Calculated Velocities for the TNT/Graphite Core

Inches per Microsecond

$\begin{array}{llll} & \frac{\text { Test 1 }}{\text { Aest 2 }} & \frac{\text { Test 3 }}{0.09} \\ \text { B } & 0.08 & 0.15 & 0.09 \\ \text { C } & 0.07 & 0.11 & 8.88 * \\ \text { D } & 0.12 & 0.16 & 0.10 \\ & 0.13 & 0.12 & 0.09\end{array}$

*This value is obviously in error.

The average velocity obtained for each test is:
1. Control Test 1
$0.10 \mathrm{in} . / \mu \mathrm{sec}$
2. Control Test 2
$0.13 \mathrm{in} . / \mu \mathrm{sec}$
3. Control Test 3
0.09 in. $/ \mu \mathrm{sec}$

The average velocity for the three tests is 0.11 inch per microsecond, which compares favorably with the literature value. Further, this value was expected to be lower because the graphite core was not solid graphite, and the void in the graphite no doubt reduced the shock-wave velocity through the material.

\section{Atmospheric Shock Overpressure Gages}

The overpressure measuring system monitored the overpressure from about 8 feet to about 40 feet from ground zero (GZ). The pressures measured for the three control tests are given in Table IV.

\section{TABLE IV}

Atmospheric Shock Overpressure Measurements

\begin{tabular}{|c|c|}
\hline $\begin{array}{l}\text { Distance } \\
\text { from GZ }\end{array}$ & $\begin{array}{l}\text { Press. } \\
\text { (peak) }\end{array}$ \\
\hline $7^{\prime} 10^{\prime \prime}$ & 15 psi \\
\hline $13^{\prime} 4^{\prime \prime}$ & 3 psi \\
\hline $23^{\prime} 4^{\prime \prime}$ & $2 \mathrm{psi}$ \\
\hline $42^{\prime} 7^{\prime \prime}$ & $1 \mathrm{psi}$ \\
\hline
\end{tabular}

302 gm TNT
Test 2

\begin{tabular}{|c|c|}
\hline $\begin{array}{l}\text { Distance } \\
\text { from GZ } \\
\end{array}$ & $\begin{array}{l}\text { Press. } \\
\text { (peak) }\end{array}$ \\
\hline $8^{\prime}$ & 21 psi \\
\hline $13^{\prime}$ & $4.5 \mathrm{psi}$ \\
\hline $22^{\prime}$ & 2 psi \\
\hline $40^{\prime}$ & $1.5 \mathrm{psi}$ \\
\hline
\end{tabular}

302 gm TNT
Test 3

\begin{tabular}{|c|c|}
\hline $\begin{array}{l}\text { Distance } \\
\text { from GZ } \\
\end{array}$ & $\begin{array}{l}\text { Press } \\
\text { (peak) }\end{array}$ \\
\hline $8^{\prime}$ & 35 psi \\
\hline $12^{\prime}$ & 5 psi \\
\hline $22.5^{\prime}$ & $3.5 \mathrm{psi}$ \\
\hline $41^{\prime}$ & 2 psi \\
\hline
\end{tabular}

456 gm TNT 
The pressures obtained in the NERVA scaled model tests and those obtained in the NERVA ful1-scale test are given in Table V.

TABLE V

NERVA Scaled Mode1 and Fu11-Scale Overpressure Measurements

Scaled Mode1

\begin{tabular}{|c|c|}
\hline $\begin{array}{l}\text { Distance } \\
\text { from GZ }\end{array}$ & $\begin{array}{l}\text { Press } \\
\text { (peak) }\end{array}$ \\
\hline $4^{\prime}$ & 17 psi \\
\hline $6^{\prime}$ & $6.5 \mathrm{psi}$ \\
\hline $8^{\prime}$ & $4.0 \mathrm{psi}$ \\
\hline $10^{\prime}$ & $3.0 \mathrm{psi}$ \\
\hline
\end{tabular}

$230 \mathrm{gm}$ TNT

\begin{tabular}{|c|c|}
\hline $\begin{array}{l}\text { Distance } \\
\text { from GZ }\end{array}$ & $\begin{array}{l}\text { Press. } \\
\text { (peak) }\end{array}$ \\
\hline $4^{\prime}$ & 12 psi \\
\hline $8^{\prime}$ & $5 \mathrm{psi}$ \\
\hline $12^{\prime}$ & 3 psi \\
\hline
\end{tabular}

220 gm DATB
Full Scale

\begin{tabular}{|c|c|}
\hline $\begin{array}{l}\text { Distance } \\
\text { from GZ }\end{array}$ & $\begin{array}{l}\text { Press. } \\
\text { (peak) }\end{array}$ \\
\hline $20^{\prime}$ & $23.0 \mathrm{psi}$ \\
\hline $30^{\prime}$ & $8.0 \mathrm{psi}$ \\
\hline $40^{\prime}$ & $4.2 \mathrm{psi}$ \\
\hline
\end{tabular}

111 1b DATB

A comparison of the pressures measured in the ROVER/PHOEBUS and the NERVA scaled-model test indicates that the attenuation through air is quite rapid, and results in nearly equal pressures at 10 to 15 feet even though the charge weight varies from 230 to 456 grams. Even when the pressures of the ROVER/PHOEBUS scaled-model tests are compared to those of the NERVA full-scale test, there is close agreement. The pressures are about $1.5 \mathrm{psi}$ at 40 feet scaled and 4.2 psi at 40 feet for full scale, and this represents 302 grams to 111 pounds of explosive.

\section{Case Rupture Instruments}

The case rupture data indicate a splitting action from the top to the bottom of the case when using the smaller explosive charges. Data from the two tests using 75.5 grams of TNT in each of the four explosive charges are given in Table VI.

TABLE VI

Case Rupture Data for ROVER/PHOEBUS Tests 1 and 2

$\begin{array}{llcc} & & \begin{array}{c}\text { Test } 1 \\ (\mu \mathrm{sec})\end{array} & \begin{array}{c}\text { Test 2 } \\ \text { Outer Pressure Vesse1 }\end{array} \\ & \text { Top } & 230 & 140 \\ \text { Bnner Support Cylinder } & \text { Tottom } & 300 & 350 \\ & \text { Bop } & 230 & 160 \\ & \text { Bottom } & 300 & 250\end{array}$


Increasing the weight of the explosive to 114 grams of TNT in each of the four explosive charges resulted in a more uniform rupturing of the case. Data from Test 3 are given in Table VII.

\section{TABLE VII}

\section{Case Rupture Data for Test 3}

$\begin{array}{lll}\text { Outer Pressure Vesse1 } & \text { Top } & 240 \mu \mathrm{sec} \\ & \text { Bottom } & 240 \mu \mathrm{sec} \\ \text { Inner Support Cylinder } & \text { Top } & 115 \mu \mathrm{sec} \\ & \text { Bottom } & 150 \mu \mathrm{sec}\end{array}$

Although a more uniform case rupture is evident, the inner support cylinder still shows rupture at the top first. The cases ruptured at the top because the explosive train was initiated at the top of the vesse1.

\section{Meta11ic Debris Distribution}

The distribution of metallic debris recovered from the three control tests is plotted in Figures 14, 15, and 16. These plots show rather clearly that the distribution was reasonably uniform and that on Tests 1 and 2 a very low radia1 velocity was imparted. Results from Test 3 indicate a greater radial velocity but still greatly reduced from the velocities experienced when the explosive charges were placed parallel to the longitudinal axis. Approximately 95 percent of the metal parts were recovered, and this indicates limited dispersion.

Figures 17 and 18 are included to show the jetting which occurred in the ROVER/NERVA tests and to show the concentration of the debris. 


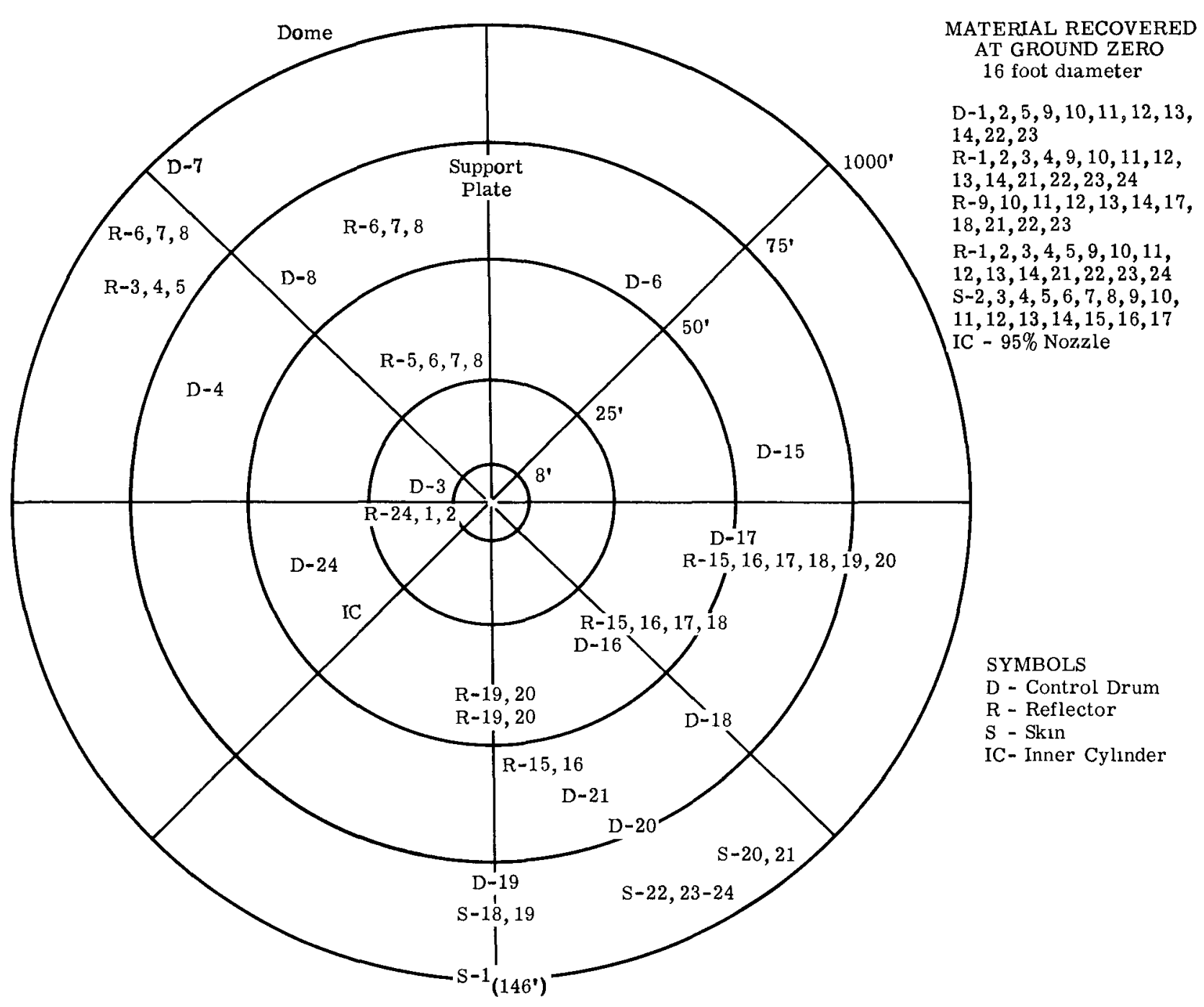

Figure 14. ROVER/PHOEBUS Test 1 meta11ic fragments distribution 


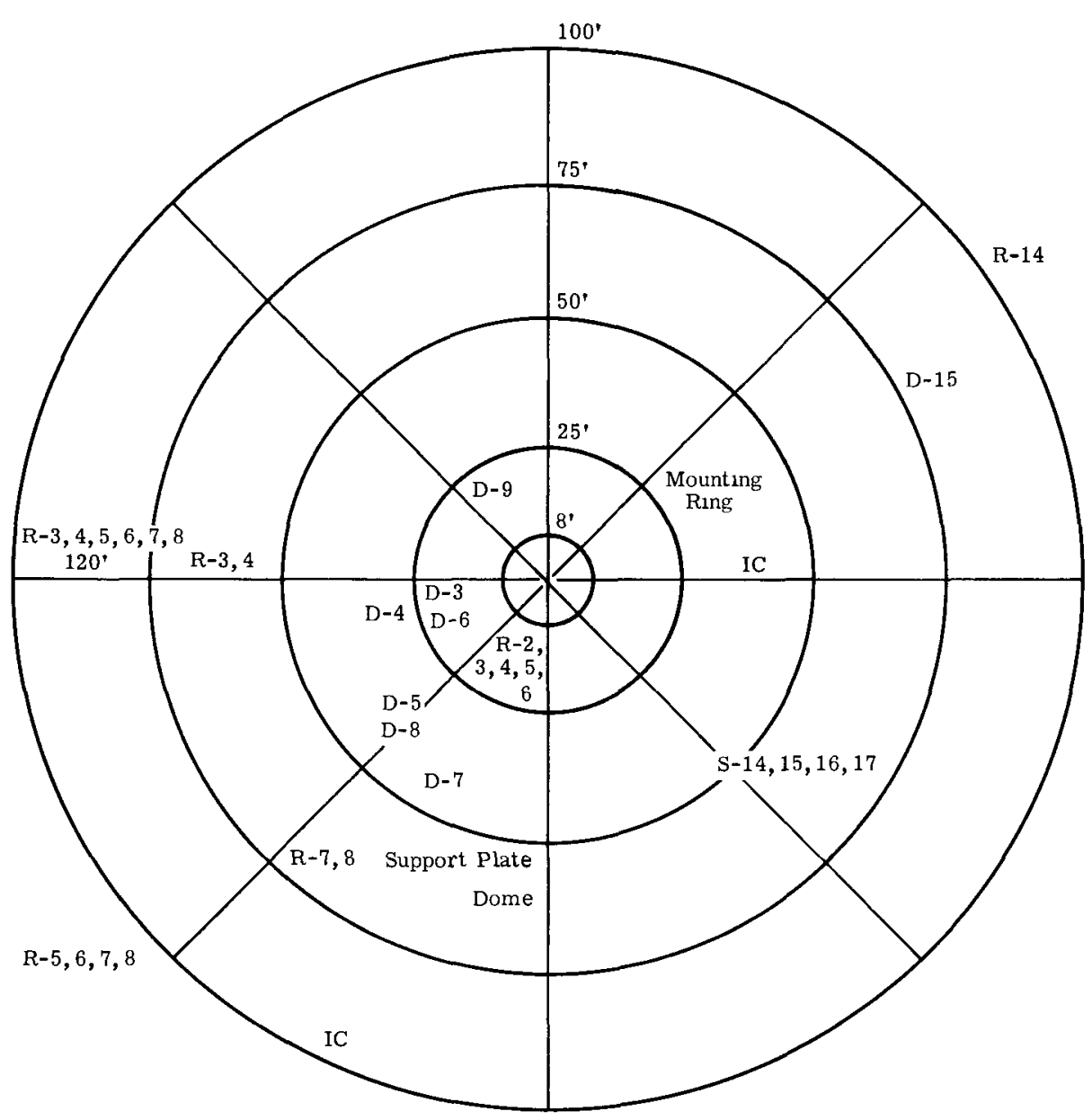

Figure 15. ROVER/PHOEBUS Test 2 metal1ic fragments distribution

Material Recovered at Ground Zero (16-foot diameter)

D (Contro1 Drum) - 1,2,16,17,18,19,20,21,22,23,24

R (Reflector) - 1,16,17,18,19,20,21,22,23,24

$1,2,15,16,17,18,19,20,21,22,23,24$

$1,2,15,16,17,18,19,20,21,22,23,24$

S (Skin)

- $1,2,3,4,5,6,7,8,9,10,11,12,13,18,19$, $20,21,22,23,24$

IC (Inner Cylinder) - 50 percent

$\mathrm{N}$

- 100 percent 


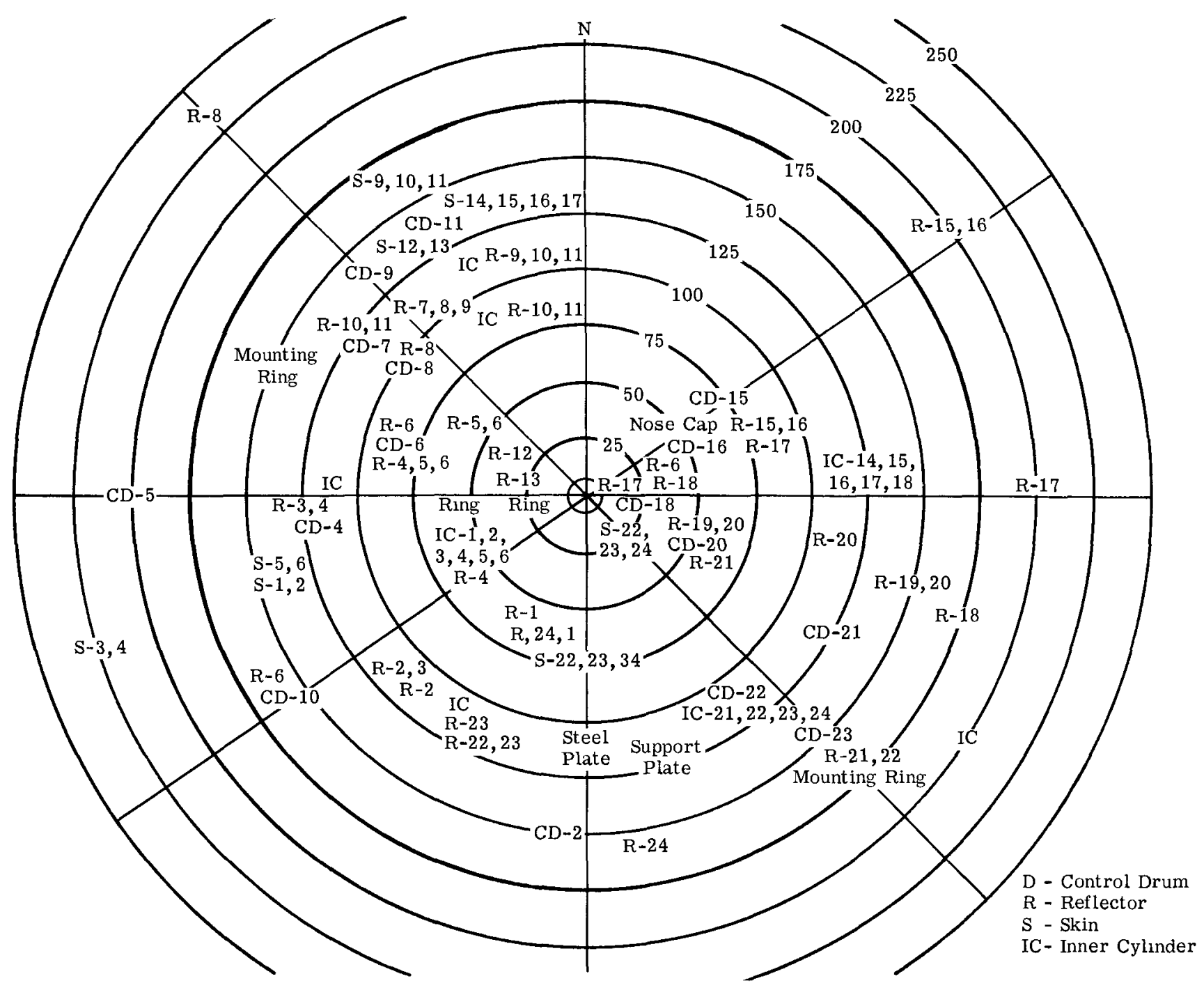

Figure 16. ROVER/PHOEBUS Test 3 metallic fragments distribution 


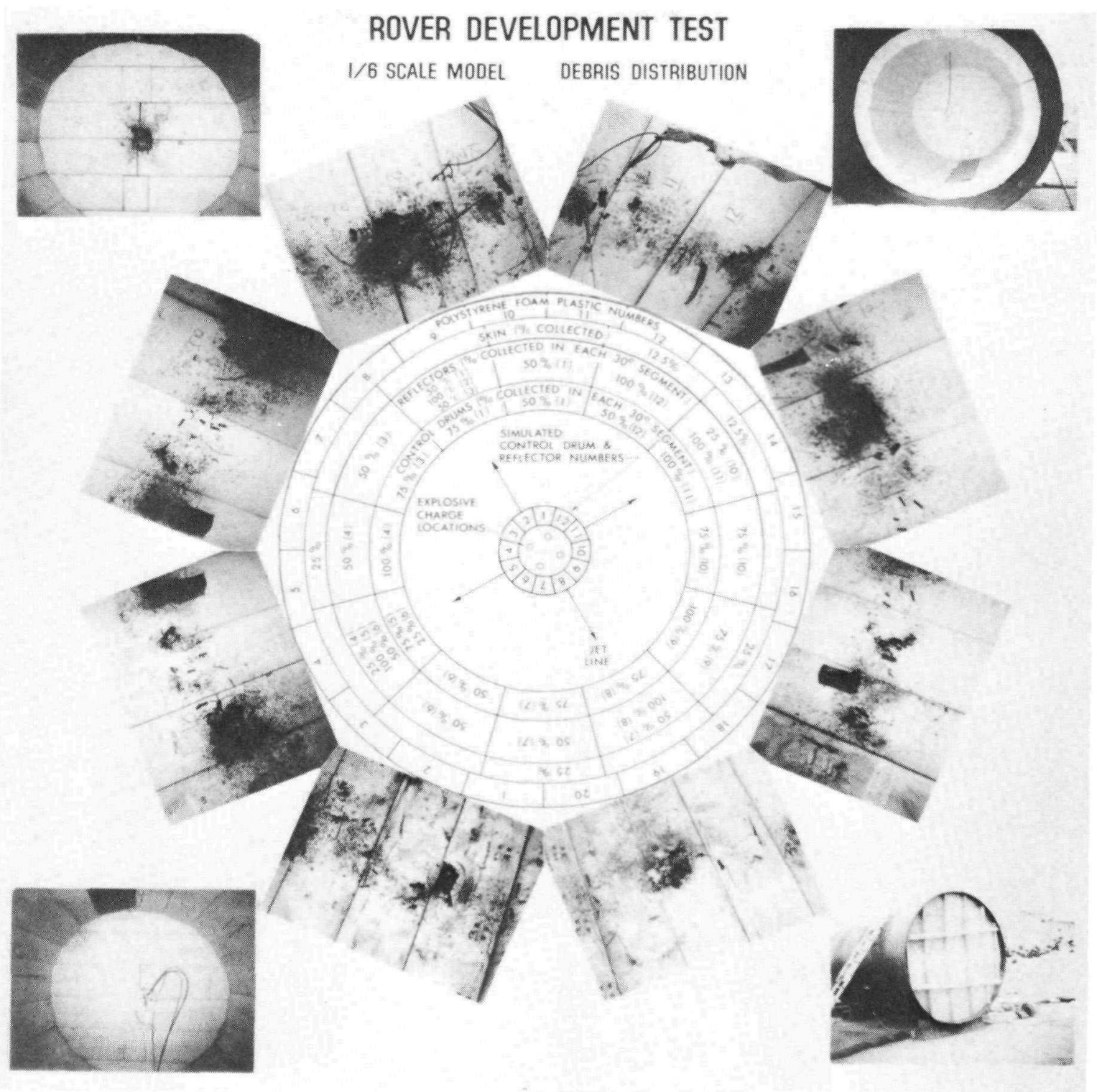

Figure 17. ROVER/NERVA scaled-mode1 debris distribution 


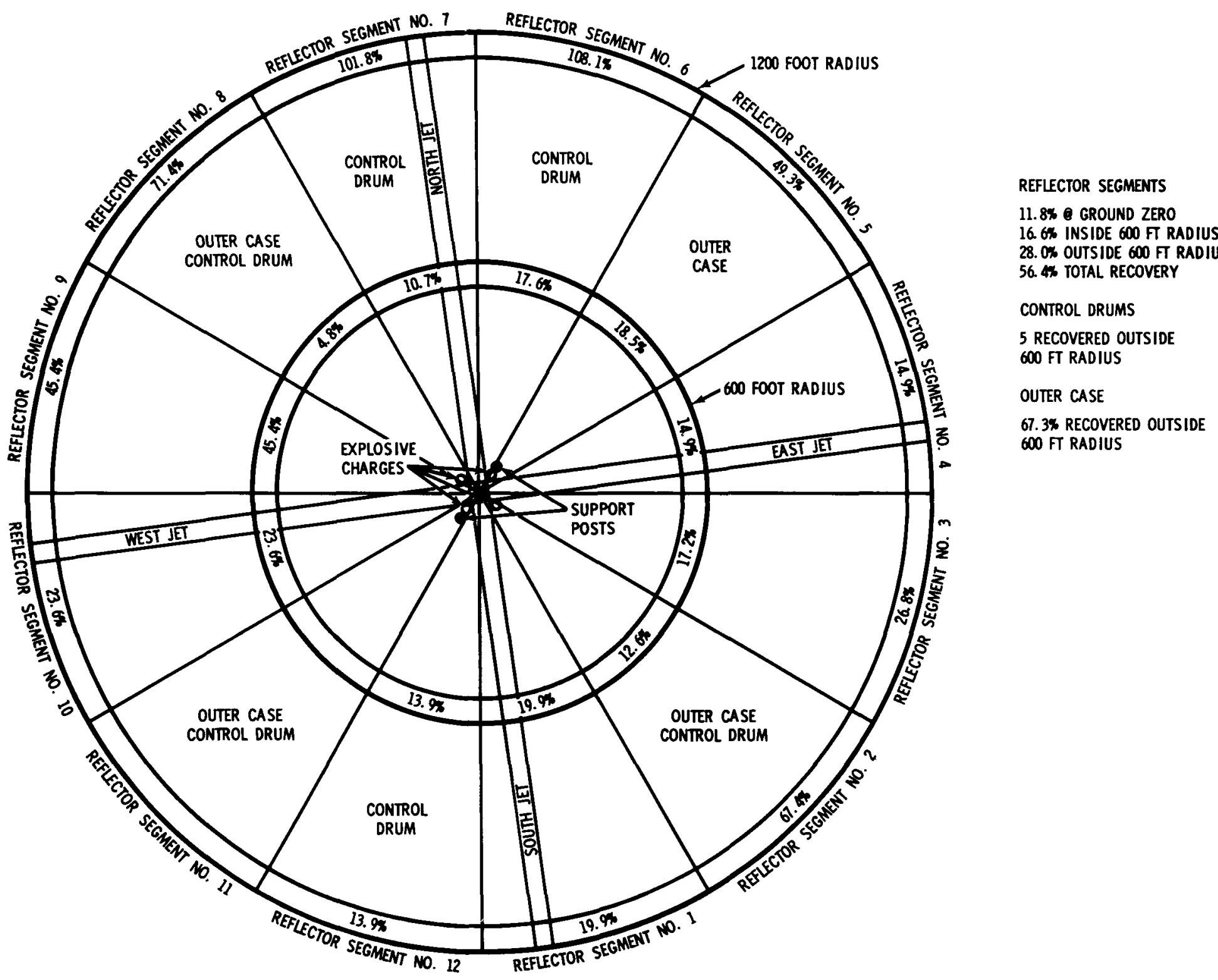

Figure 18. ROVER/NERVA full-scale debris distribution 


\section{Graphite Debris Recovery}

The recovery of graphite particles was not planned as part of these control tests. However, the extreme reduction in debris dispersion resulted in a large percentage of the graphite falling into the pit below ground zero, and recovery was very simple. The third control test produced increased graphite dispersion, and therefore a smaller percentage of it was recovered (Table VIII).

\section{TABLE VIII}

Graphite Recovery

\begin{tabular}{lrc} 
& Grams & $\begin{array}{l}\text { Percent } \\
\text { Recovery }\end{array}$ \\
\cline { 2 - 2 } Test 1 & 10747.4 & 82 \\
Test 2 & 10842.8 & 82.8 \\
Test 3 & 4794.7 & 36.6
\end{tabular}

The amount of graphite in each scaled mode1 was 13,101 grams.

\section{Graphite Debris Distribution}

The graphite debris was cleaned and graded according to size, and the results are tabulated in Tables IX, X, and XI. These data are also plotted in Figures 19,20 , and 21 as screen size versus the weight percent remaining on each screen. The data are plotted as screen size versus the accumulated weight percent (Figures 22, 23, and 24) and are compared to each other in Figure 25. The accumulation is begun at the smaller screen size and accumulated to the larger screen size. Finally, the data from these control tests (PHOEBUS mode1) are compared to the data from the Aberdeen Proving Ground (Test 3) and the scaled-model tests (NERVA mode1) performed prior to the full-scale APG-3 test (Figure 26).

\section{Conclusions and Recommendations}

The three control tests performed on the PHOEBUS scaled model were intended to provide base-line information about the debris cloud shape and the debris distribution pattern. These data were needed to serve as comparative values when data were obtained from tests which were perturbed in a specified manner. The perturbations to be programmed were: (1) varying the entry angle of the explosive charge from the nominal, (2) firing the detonators in a nonsimultaneous pattern, and (3) destroying the test vessel with the core heated to near reactor operating temperature. 
The control tests indicated that perturbations in (1) and (2) would not be observable using the existing test conditions and exp1osive charge weights. Graphite temperature information indicated that the core temperature needed for (3) could not be acquired without cooling the metal components. These tests did show that when the explosive charges are emplaced skewed (across a quadrant of the core) jetting does not occur. Further, these tests indicated that the amount of explosive used was insufficient to impart any appreciable radial velocity to the graphite core material.

The results obtained using scaled $120-\mathrm{mm}$ and $155-\mathrm{mm}$ charges show that the amount of explosive needed to cause breakup comparable to that of the NERVA models is not a straight volume function. This conclusion was reached by comparing the particle size achieved from a NERVA model test using scaled $105-\mathrm{mm}$ explosive charges and the particle size achieved from a PHOEBUS model test using scaled $155-\mathrm{mm}$ explosive charges. The same volume of core-to-explosive-volume ratio was used in both tests.

The completed tests indicated a need for redirecting the test program, and therefore a11 the remaining tests scheduled in the test plan were canceled.

The need for obtaining comparative data between skewed charges and para1lel charges is evident. Therefore, it is recommended that at least two tests using parallel charges be performed; one test should use scaled $120-\mathrm{mm}$ explosive and the other should use scaled 155-mm. Extreme jetting was observed in the NERVA scaled model, and the data available do not indicate whether the lack of jetting in the PHOEBUS test occurred because of increased test vessel size or skewed charge arrangement. 
TABLE IX

Graphite Debris Distribution
for Test 1

US Standard Sieves Size (mm)

19.0

13.5

9.51

6.73

4.76

3.36

2.38

1.68

1.19

0.841

0.595

0.420

0.297

0.210

0.149

0.105

0.074

0.053

0.037

bottoms

\begin{tabular}{c} 
Weight Percent \\
\hline 0.5 \\
0.8 \\
1.7 \\
6.5 \\
14.5 \\
20.4 \\
16.5 \\
8.8 \\
5.3 \\
6.4 \\
3.2 \\
2.8 \\
2.3 \\
2.0 \\
1.8 \\
1.9 \\
1.8 \\
0.8 \\
0.8 \\
1.4
\end{tabular}

Accumulative Weight
100.0

99.5

98.8

97.1

90.5

76.0

55.6

39.1

30.3

25.0

18.6

15.4

12.6

10.3

8.3

6.6

4.7

2.9

2.1

1.4 
TABLE $X$

\section{Graphite Debris Distribution}

\begin{tabular}{ccc}
$\begin{array}{c}\text { UStandard Sieves } \\
\text { Size (mm) }\end{array}$ & Weight Percent & $\begin{array}{r}\text { Accumulative Weight } \\
\text { (\%) }\end{array}$ \\
\cline { 3 - 3 } 19.0 & 0.5 & 100.0 \\
13.5 & 0.7 & 99.5 \\
9.51 & 2.0 & 98.7 \\
6.73 & 8.0 & 96.7 \\
4.76 & 19.9 & 88.7 \\
3.36 & 21.4 & 68.8 \\
2.38 & 13.2 & 47.4 \\
1.68 & 8.4 & 34.3 \\
1.19 & 5.1 & 25.9 \\
0.841 & 4.3 & 20.7 \\
0.595 & 2.7 & 16.4 \\
0.420 & 2.7 & 13.7 \\
0.297 & 2.0 & 11.0 \\
0.210 & 1.9 & 9.0 \\
0.149 & 1.7 & 7.2 \\
0.105 & 1.5 & 5.4 \\
0.074 & 1.2 & 3.9 \\
0.053 & 0.7 & 2.7 \\
0.037 & 0.9 & 2.0 \\
bottoms & 1.1 & 1.1
\end{tabular}


TABLE XI

Graphite Debris Distribution
for Test 3

US Standard Sieves Size (mm)

19.0
13.5
9.51
6.73
4.76
3.36
2.38
1.68
1.19
0.841
0.595
0.420
0.297
0.210
0.149
0.105
0.074
0.053
0.037
bottoms

\begin{tabular}{c} 
Weight Percent \\
\hline 0.1 \\
0.8 \\
1.3 \\
5.7 \\
7.8 \\
17.0 \\
16.1 \\
11.9 \\
7.4 \\
6.1 \\
4.6 \\
4.3 \\
3.4 \\
3.2 \\
3.0 \\
2.4 \\
1.9 \\
0.9 \\
0.8 \\
1.4
\end{tabular}

Accumulative Weight

Size $(\mathrm{mm})$




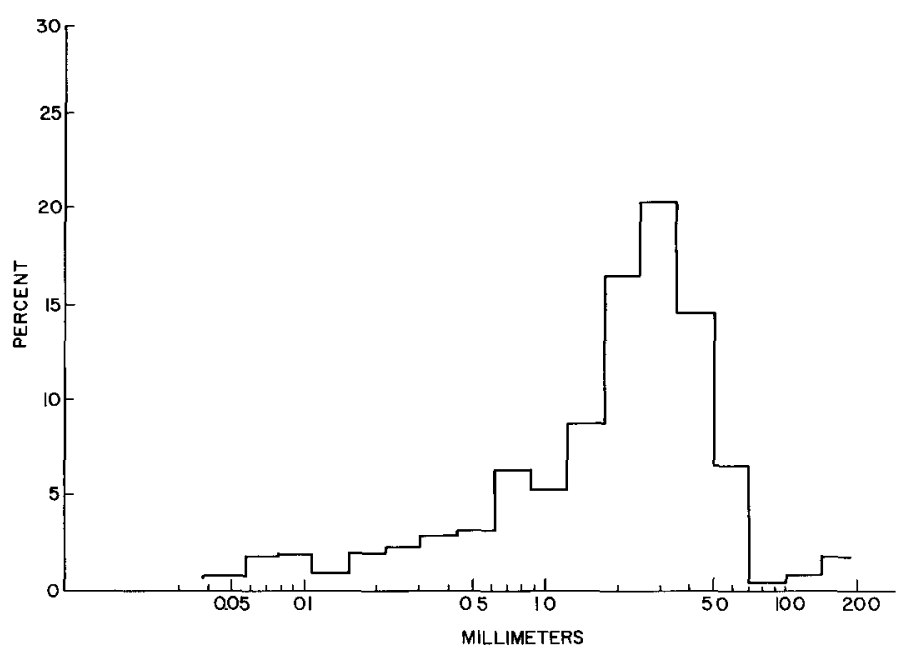

Figure 19.

Jontrol Test 1 -- Particle size versus weight percent

Figure 20.

Control Test 2 -- Particle size versus weight percent
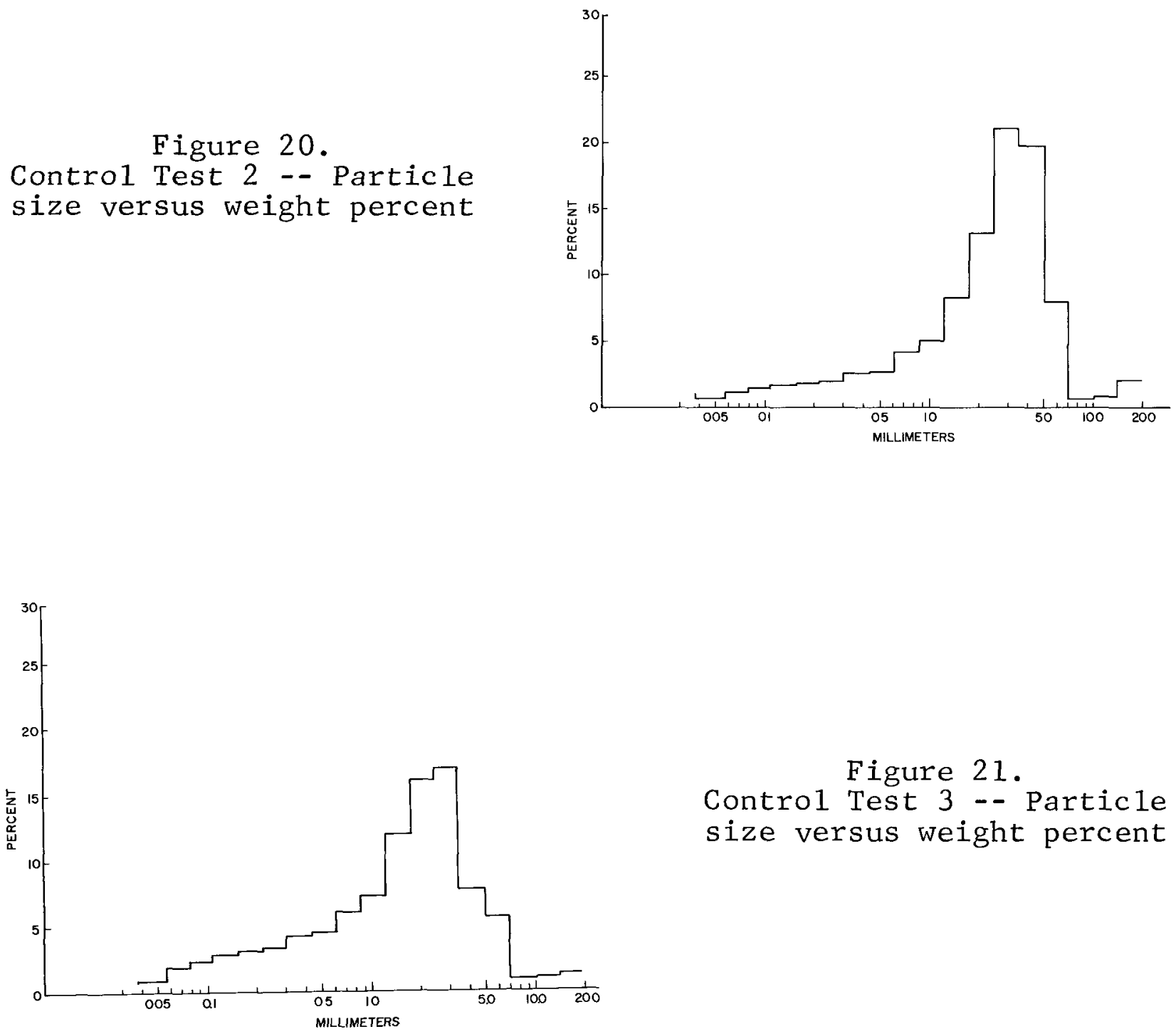

Figure 21.

Control Test 3 -- Particle size versus weight percent 


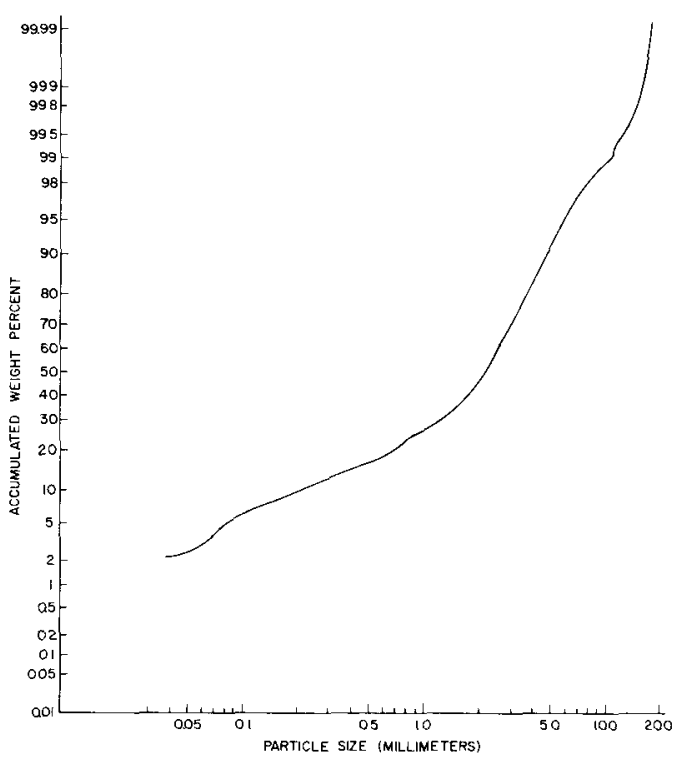

Figure 23.

Control Test 2 -- Particle size versus accumulated weight percent
Figure 22 .

Control Test 1 -- Particle size versus accumulated weight percent
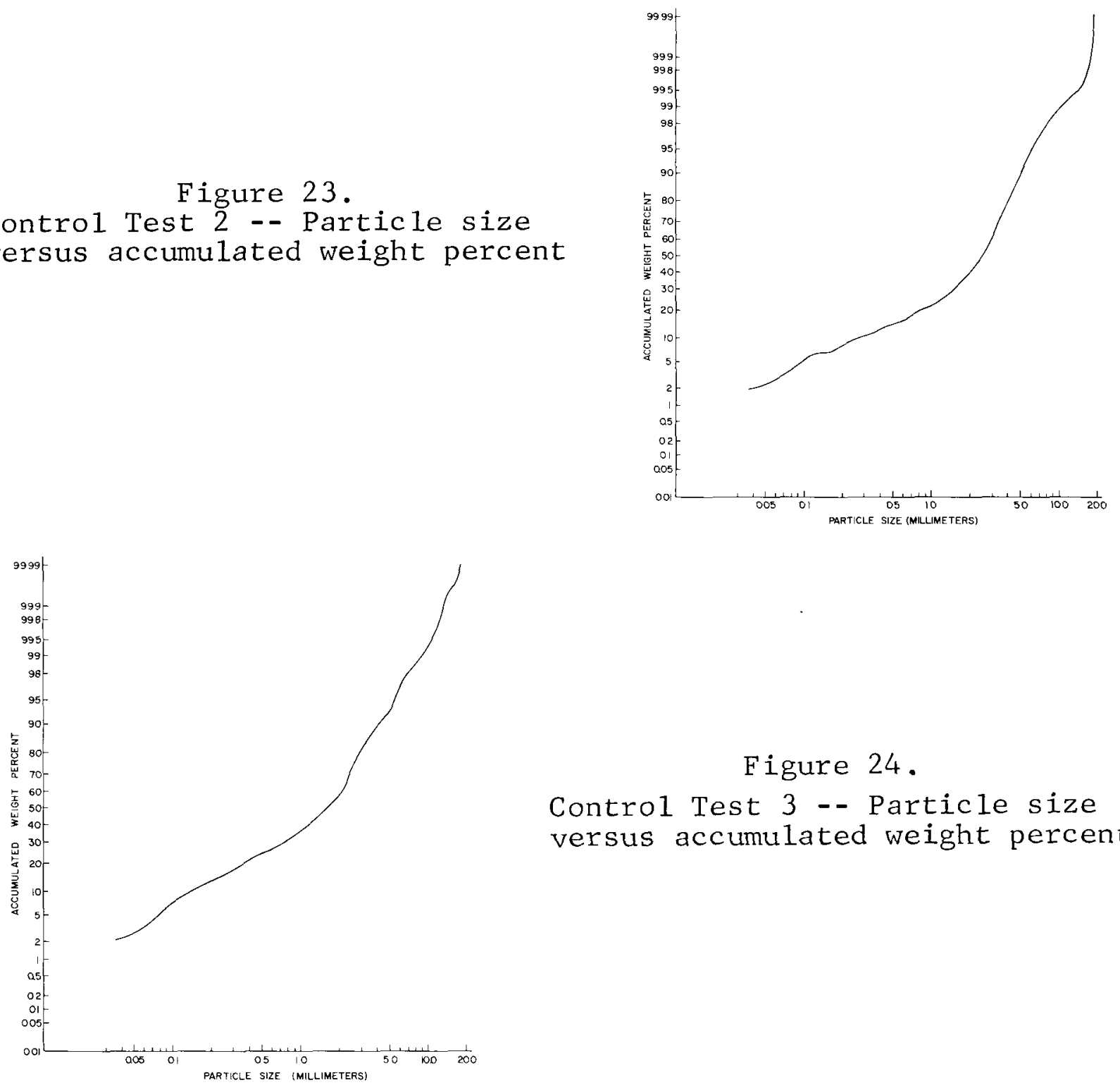

Figure 24.

Control Test 3 -- Particle size versus accumulated weight percent 


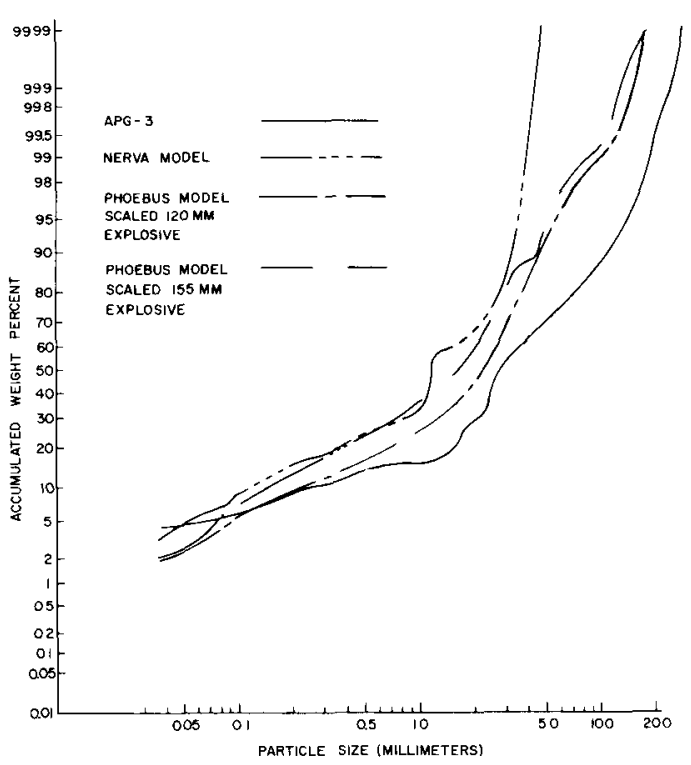

Figure 26. Data comparison particle size versus accumulated weight percent
Figure 25. Control test comparison -- particle size versus accumulated weight percent

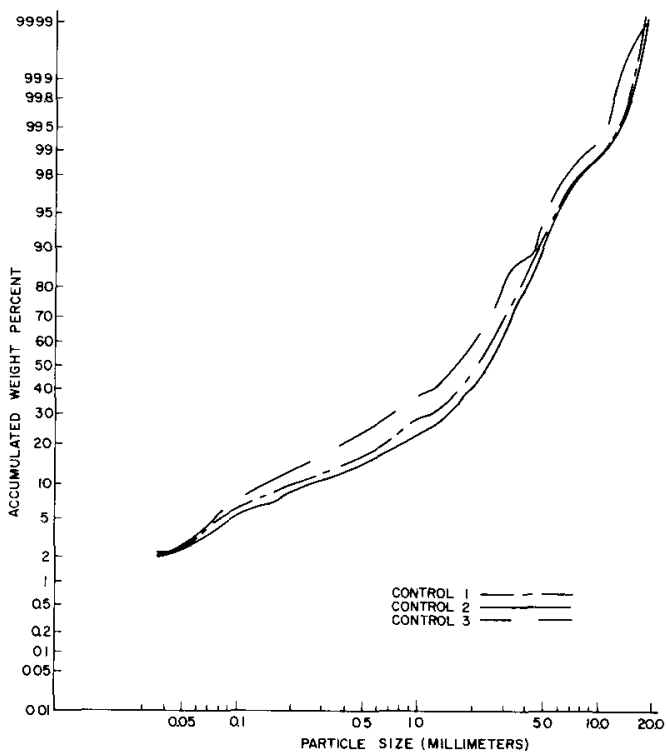




\section{References}

1. SC-RR-65-551, ROVER Postoperationa1 Destruct Instrumentation Development, R. E. Berry and J. P. Martin, Sandia Corporation, Albuquerque, New Mexico, December 1965.

2. SC-RR-65-557, Evaluation of Microscopic-Sized Graphite Aerosol from a ROVER Reactor Destruct Test June 1965, D. R. Parker, Sandia Corporation, Albuquerque, New Mexico, December 1965.

3. SC-RR-65-620, ROVER/NERVA Destruct System Test Resu1ts Aberdeen Proving Ground - 3 (Fina1 Report), R. E. Berry and J. P. Martin, Sandia Corporation, Albuquerque, New Mexico, December 1965. 
Blank Page 
APPENDIX A

ROVER/PHOEBUS Scale-Mode1 Test Program 
Blank Page 
APPENDIX A

ROVER/PHOEBUS SCALE-MODEL TEST PROGRAM

(Development of Destruct Systems Instrumentation)

R. E. Berry, Div. 9312

R. R. Middlesworth, Div. 9312

J. P. Martin, Div. 9232

ABSTRACT

The ROVER/PHOEBUS test program is proposed to partially fulfill Sandia Corporation's responsibility to the AEC for the safety evaluation of nuclear power supplies to be used in space. This test series will provide needed information about the effects of (1) varying the entry angle of skewed charges, (2) varying the nonsimultaneity of multiple charge firing, and (3) a hot core (therma1) on particle size distribution. 


\section{SUMMARY}

The ROVER/PHOEBUS test program is a follow-on series of explosive destruct tests to provide further information about the postoperational destruct of a nuclear propulsion engine after use in space. These tests are requested by the joint AEC/NASA Space Nuclear Propulsion Office.

The test program will be performed as a partial fulfillment of Sandia Corporation's responsibility to the AEC for the safety evaluation of nuclear power supplies to be used in space.

Data will be collected on the effects of varying the entry angle of the explosive charges, varying the detonation nonsimultaneity, and thermally heating the core material. All of the proposed tests will provide data about the debris distribution, the particle size distribution, and the velocity of the debris generated by the explosive destruct of the ROVER/PHOEBUS scale-model propulsion engine. 
ROVER/PHOEBUS SCALE-MODEL TEST PROGRAM

\section{Introduction}

Following completion of the development testing of the scale models (NERVA) and the evaluation of the acquired data, a full-scale mockup of the ROVER/NERVA propulsion engine was destroyed in June 1965 under the direction of the AEC/NASA Space Nuclear Propulsion Office, and was a joint test by Aberdeen Proving Ground, Picatinny Arsena1, and Sandia Corporation. The mockup space engine contained a simulated core, control drums, reflector segments, core support plate, shield, and outer pressure vessel. The space engine was destroyed by four statica11y emplaced $105-\mathrm{mm}$ special explosive charges. The destruct test was performed to provide debris distribution, size, and velocity data.

Although the full-scale destruct test was a success, more data are needed about other aspects of the destruct system and therfore a second series of tests are to be run on the ROVER/PHOEBUS propulsion engine.

A meeting was held October 14-15, 1965, at Aberdeen Proving Ground to review the full-scale destruct test data and to plan the follow-on testing. The areas which need further investigating are:

1. The effects of various explosives on particle size distribution.

2. The effects of increasing charge weight (charge-tomass-ratio increase) on debris distribution and size.

3. The effects of changing the number of charges on debris distribution.

4. The effects of having the charges fail to penetrate or penetrate too far into the core.

5. The effects of varying the skewed angle of charge penetration on core breakup.

6. The effects of a cold core versus a hot core (thermal) on particle size distribution.

7. The effects of nonsimultaneous detonation of the charges. 
Items $1,2,3$, and 4 of the above seven categories will be tested by a joint Aberdeen/Picatinny test program using a Sandiadesigned scale-model test vessel, simulating the NERVA-2 (PHOEBUS) space engine. Items 5, 6, and 7 will be tested by Sandia Corporation.

A11 tests except Item 1 will be performed using TNT as the explosive, and the Sandia tests will al1 be performed using skewed angle charge position.

Sandia will perform this test series in Area X, either at the "swimming pool" facility or within the 30-foot diameter steel tank. A11 tests will be base-detonated and will be fired with precise simultaneity except for the tests to determine nonsimultaneity effects.

Los Alamos Scientific Laboratory suggested at a meeting on November 29, 1965, that Sandia investigate the fuel element breakup and explosive shock-wave propagation when using a single centrally located explosive charge. This investigation would provide data for comparing the results of one explosive charge, four explosive charges, and four explosive charges in a full-scale test vehicle.

\section{Description of Tests}

In an effort to gain a better understanding of the breakup mechanics and the particle sizes resulting from a post-space flight destruct of a ROVER/PHOEBUS nuclear propulsion engine using four skewed explosive charges, a series of 1/6-scale ROVER/PHOEBUS models (Drawing No. N99888, CRD) will be destroyed. The Sandia test program will be performed and reported as Photo, Control, Simultaneity, Skewed Angle, and Therma11y Hot Core tests.

\section{Photo Tests}

The Photo series, designated as A, B, C, and D, will be run using solid graphite cylinders with an explosive charge located along the centerline of the cylinder. These tests are planned to perfect photographic coverage of tests conducted in the 30-foot diameter tank. The only instrumentation will be photographic.

\section{Contro1 Tests}

The Contro1 series, designated as Tests $1,2,3,4$, and 5 , will use the 1/6-scale models to provide control or reference data for comparison with the remaining tests. Test 3 will use a ROVER/ NERVA scale mode1. 
Test 1

Test 1 will be conducted at the outside swimming pool facility in Sandia's Area $X$. This test will be performed to establish the debris pattern by photographic coverage so the future tests can be instrumented properly. The only instrumentation on Test 1 will be photographic coverage and a system to determine the delay between charge detonation and the resulting rupture of the external case. Instrumentation will be held to a minimum so that optimum photographic coverage can be obtained.

Test 2

Test 2 will be fired using the same instrumentation as Test 1 , but will be canceled if adequate information is obtained on Test 1 .

\section{Test 3}

Test 3 will be performed in the tank facility and wi11 use a NERVA scale mode1. This 1/6-scale mode1 will be destroyed with one centrally located explosive charge and will provide particle size data which can be compared to particle size data from tests using four explosive charges (both scale model and full scale). The correlation of these data will yield information about the effect of shock propagation distance. Instrumentation for this test will consist of photographic coverage, measurement of case breakup time, and fixed foam particle collectors. This test may be performed by $A P G / P A$ in their number of charges test series or it may be dropped if sufficient data can be obtained from past tests.

\section{Test 4}

Test 4 will be conducted in the tank facility using a 1/6-scale model. The primary purpose of this test is to determine the particle size distribution for use as reference for future tests. Instrumentation on this test will consist of photographic coverage, measurement of case breakup time, particle velocity measurements, and fixed foam particle collectors.

\section{Test 5}

Test 5 will be performed in the same manner as Test 4 with one exception. The core will consist of D-38 (depleted uranium) loaded graphite. The loaded core is used because previous tests performed by Los Alamos Scientific Laboratory indicated that the loaded core breaks up differently from an unloaded core. The same instrumentation will be employed on Test 5 as used in Test 4. This test completes the series of Control tests. 


\section{Simultaneity Tests}

The Simultaneity test series, designated $6,7,8$, and 9 , will determine the effect on particle size distribution of varying the nonsimultaneity of detonating the four charges.

\section{Test 6}

Test 6 will be performed with charge No. 1 delayed by 18 microseconds and the remaining three charges fired simultaneously. Instrumentation will consist of photographic coverage, measurement of case break time, and fixed foam particle collectors.

\section{Test 7}

Test 7 will have charge No. 1 delayed by one-half the case break time measured on Tests 1,2 , and 4 . Instrumentation will be the same as Test 6 .

\section{Test 8}

Test 8 will have charge No. 1 delayed by one times the case break time measured on Tests 1,2 , and 4 . Instrumentation wil1 be the same as used on Test 6 .

\section{Test 9}

Test 9 will have charges No. 1 and 3 delayed as determined by previous tests $(6,7$, and 8$)$. Instrumentation will be the same as used on Test 6 .

\section{Skewed Angle Tests}

The Skewed Angle series, designated Tests 10 and 11 , wi11 show the effects on particle size distribution of varying the location of the four charges about their normal position in the core. Figure A-la shows the nominal or normal position for the four explosive charges. Figure A-lb shows the approximate location of the four explosive charges for Test 10 and Figure A-1c shows the approximate location of charges for Test 11. Figure A-1d shows the approximate locations of the nose of the projectile which were considered when selecting the locations for Tests 10 and 11 . Positions 1 and 2 are the ones selected for test. The instrumentation for this series of tests will consist of photographic coverage, measurement of case break time, velocity measurements, and fixed foam particle collectors. 


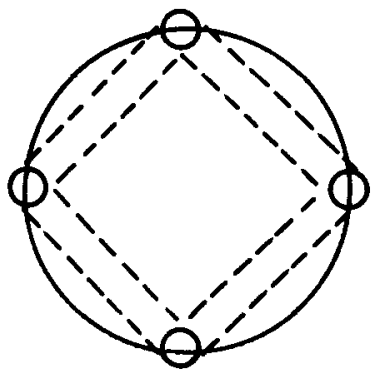

a

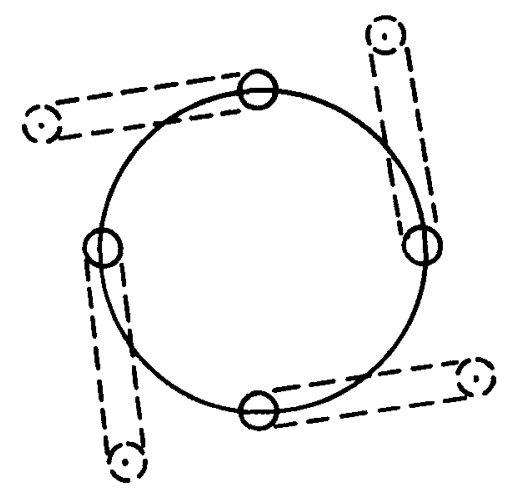

C
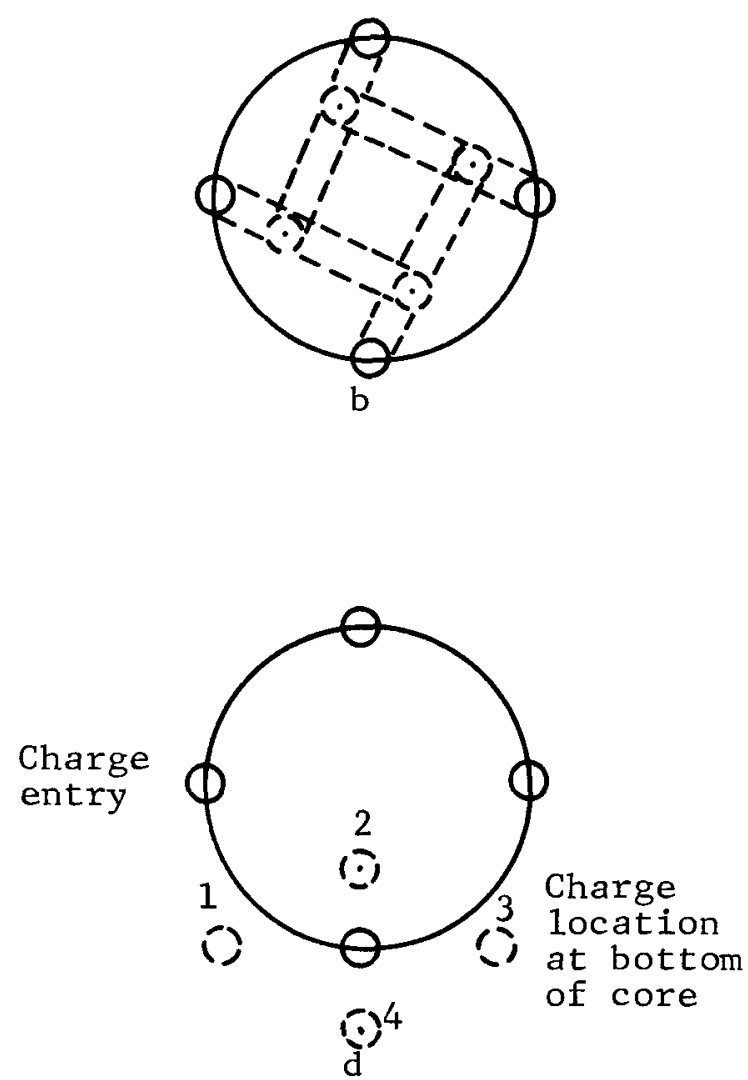

Figure A-1. Skewed charge locations for test

\section{Thermally Hot Core Tests}

The final series of tests, designated Tests 12 and 13 , will be performed using scale models with thermally hot D-38 loaded graphite cores. These tests will be performed to illustrate the effect on particle size distribution of a heated core. Test 12 will have the core at approximately $2000^{\circ} \mathrm{F}$ and Test 13 will have the core at approximately $3000^{\circ} \mathrm{F}$. The tests will be performed in the tank facility with photographic coverage, velocity measurements, and fixed foam particle collectors.

\section{Conclusion}

The entire test series is tabulated in Table A-1. This table shows the interrelationship of the tests and the tentative test dates.

Although the majority of tests are scheduled for completion in the 30-foot diameter tank, some may be run at the "swimming pool" to allow better instrumentation coverage of the test.

These tests will be used to further develop instrumentation as we11 as provide the data indicated under each test series. 


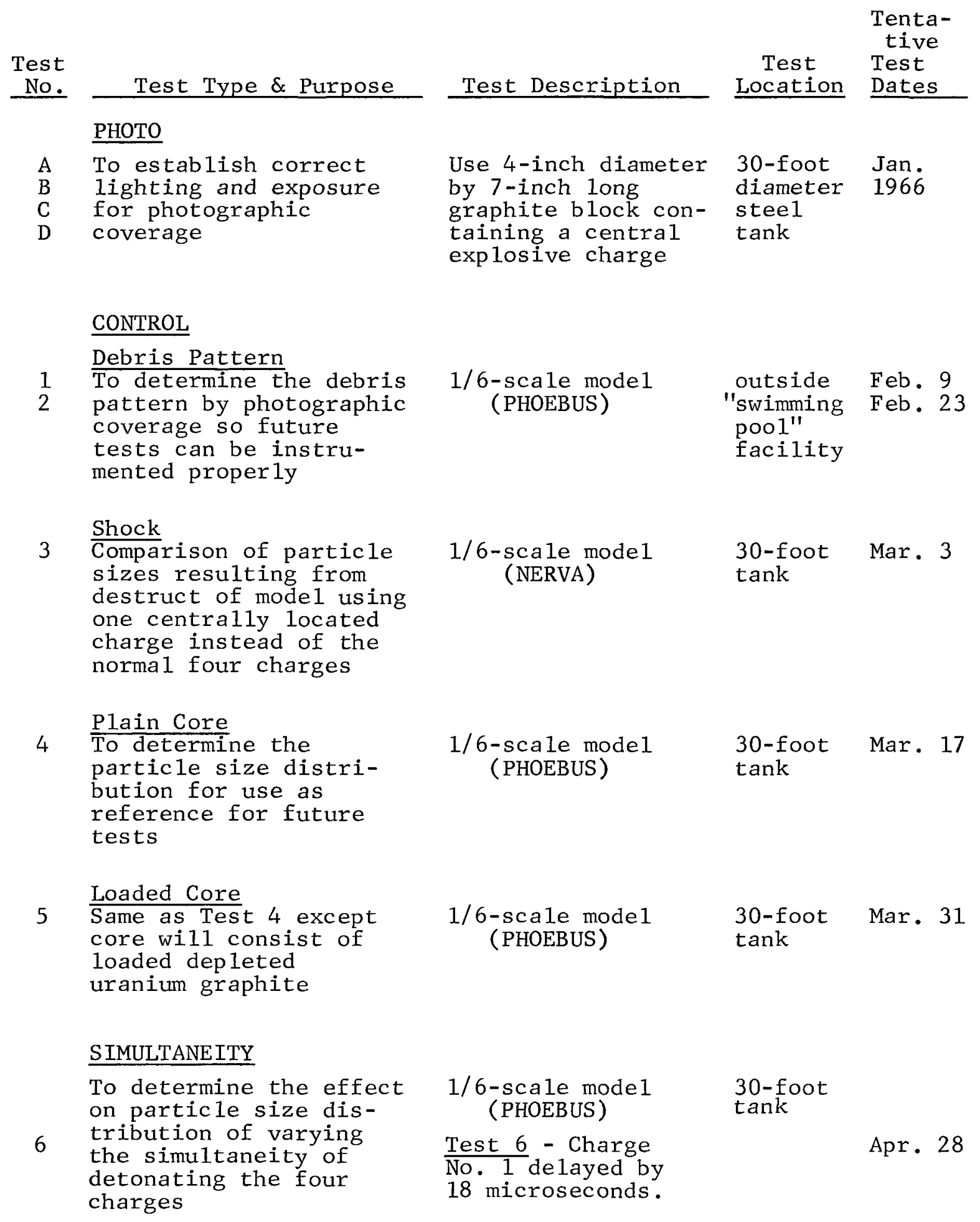




\begin{tabular}{|c|c|c|c|c|}
\hline $\begin{array}{l}\text { Test } \\
\text { No. }\end{array}$ & Test Type \& Purpose & Test Description & $\begin{array}{c}\text { Test } \\
\text { Location } \\
\end{array}$ & $\begin{array}{l}\text { Tenta- } \\
\text { tive } \\
\text { Test } \\
\text { Dates } \\
\end{array}$ \\
\hline 7 & & $\begin{array}{l}\text { Test } 7 \text { - Charge } \\
\text { No } 1 \text { delayed by } \\
1 / 2 \text { case break } \\
\text { time measured in } \\
\text { Tests } 1,2 \text {, and } 4 .\end{array}$ & & May 12 \\
\hline 8 & & $\begin{array}{l}\text { Test } 8 \text { - Charge } \\
\text { No. } 1 \text { delayed by } \\
\text { one case break } \\
\text { time measured in } \\
\text { Tests } 1,2 \text {, and } 4 .\end{array}$ & & May 26 \\
\hline \multirow[t]{3}{*}{9} & & $\begin{array}{l}\text { Test } 9 \text { - Charges } \\
\text { No. } 1 \text { and } 3 \text { delayed } \\
\text { as determined by } \\
\text { previous tests }(6, \\
7, \text { and } 8) \text {. }\end{array}$ & & June 9 \\
\hline & \multicolumn{4}{|l|}{ SKEWED } \\
\hline & \multirow{3}{*}{$\begin{array}{l}\text { To determine the } \\
\text { variation in particle } \\
\text { size caused by locat- } \\
\text { ing the charges at } \\
\text { various angles within } \\
\text { the core }\end{array}$} & $\begin{array}{c}1 / 6 \text {-scale mode } 1 \\
\text { (PHOEBUS) }\end{array}$ & \multirow[t]{3}{*}{$\begin{array}{l}30-\text { foot } \\
\text { tank }\end{array}$} & \\
\hline 10 & & $\begin{array}{l}\text { Test } 10 \\
\text { in Figure As shown } \\
\text { A-lb }\end{array}$ & & Ju1. 7 \\
\hline \multirow[t]{3}{*}{11} & & $\begin{array}{l}\text { Test } 11-\text { As shown } \\
\text { in Figure } A-1 c\end{array}$ & & Jul. 21 \\
\hline & $\underline{\mathrm{HOT}}$ & & & \\
\hline & \multirow{3}{*}{$\begin{array}{l}\text { To illustrate the } \\
\text { effect on particle } \\
\text { size distribution } \\
\text { of a heated core }\end{array}$} & $\begin{array}{c}\text { 1/6-scale mode } 1 \\
\text { (PHOEBUS) }\end{array}$ & \multirow[t]{3}{*}{$\begin{array}{l}30-\text { foot } \\
\text { tank }\end{array}$} & \\
\hline 12 & & $\frac{\text { Test } 12}{\text { core } 2000^{\circ} \mathrm{F}}$ & & Aug. 18 \\
\hline 13 & & $\frac{\text { Test } 13}{\text { core } 3000^{\circ} \mathrm{F}}$ & & Sept. 1 \\
\hline
\end{tabular}


DISTRIBUTION:

U.S. Atomic Energy Commission Director, Space Nuclear Systems Space Electric Power Office Washington, D.C. 20545 Attn:

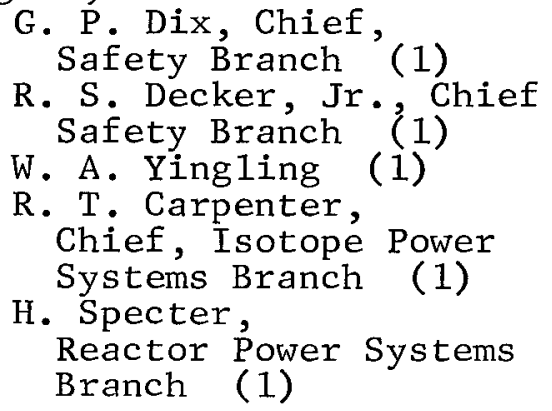

U.S. Atomic Energy Commission Space Nuclear Propulsion Office Albuquerque Extension Albuquerque Operations office P.O. Box 5400

Albuquerque, New Mexico

Attn: H. P. Smith

U.S. Atomic Energy Commission Division of Isotope Development Washington, D.C. 20545

Attn: W. K. Kern

U.S. Atomic Energy Commission Division of Safety Standards (Beth 010)

Washington, D.C. 20545

Attn: J. J. Dinunno Assistant Director, Reactors

U.S. Atomic Energy Commission Division of Biology and Medicine Washington, D.C. 20545

Attn: J. Z. Holland, Chief Fallout Studies Branch H. D. Bruner, Asst. Dir. Medical and Health Research (1)

U.S. Atomic Energy Commission

Division of Technical Information Headquarters Library G-017 Washington, D.C. 20545

U.S. Atomic Energy Commission Albuquerque Operations Office P.0. Box 5400

Albuquerque, New Mexico 87115

Attn: S. A. Upson, Director Research and Classification Div.

V. C. Vespe, Director Operationa 1 Safety Division

(1)
U.S. Atomic Energy Commission Canoga Park Area Office P.O. Box 591

Canoga Park, California

Attn: C. R. Malmstrom

U.S. Atomic Energy Commission Chicago Operations Office 9800 South Cass Avenue Argonne, I11inois 60439

Attn: Chief, Office Services Branch

U.S. Atomic Energy Commission Oak Ridge Operations Office

Mail and Document Accountability

Section, P.O. Box E

Oak Ridge, Tennessee 37831

Attn: Director, Research and Development Division

Headquarters

Air Force Systems Command (SCIZN)

Washington, D.C. 20331

Attn: Nuclear Safety Branch

Air Force Weapons Laboratory

Kirtland Air Force Base,

New Mexico

Attn: Lt. Col. H. L. Harris (WLAS)

Air University Library

Maxwe11 Air Force Base, Alabama

Attn: Elizabeth C. Pittman

Atomics International (2)

P.0. Box 309

Canoga Park, California 91304

Attn: R. L. Detterman

Batte1le Memoria1 Institute

505 King Avenue

Columbus, Ohio 43201

Attn: J. E. Davis Projects Administrator

Battelle Memoria1 Institute Pacific Northwest Laboratory P.0. Box 999

Richland, Washington 99352

Attn: E. A. Coppinger (1)

Dr. Roy Thompson

M. T. Walling

The Boeing Company

Aerospace Group

P.O. Box 3707

Seattle, Washington 98124

Attn: T. L. Smith, Mail Stop 
DISTRIBUTION (cont):

Brookhaven National Laboratory

Technical Information Division

Upton, Long Island, New York 11973

Attn: Research Library

Director, Defense Atomic Support

Agency, P.O. Box 2610

Washington, D.C. 20301

Attn: Document Library Branch

Douglas Aircraft Company, Inc.

Missile and Space Systems Division

3000 Ocean Park Boulevard

Santa Monica, California

Attn: Sig Gronich

Advanced Space Technology

E. I. du Pont de Nemours and Co.

Savannah River Laboratory

Aiken, South Carolina 29802

Attn: W. B. Scott, Document Div.

General Atomic Division

Genera1 Dynamics Corporation

P.0. Box 608

San Diego, California 92112

Attn: Library

Genera1 Electric Company

Nuclear Materials and

Propulsion Operation

P.O. Box 15132

Cincinnati, Ohio 45215

Attn: J. W. Stephenson

For: W. Briskin

Genera1 Electric Company

Valley Forge Space Technology

Center, P.O. Box 8555

Philadelphia, Pennsylvania 19101

Attn: S. M. Scala, Rm. M9539 Space Sciences Lab.

Car1 Gamertsfelder, Advanced Requirements Planning Dept.

General Electric Company

570 Lexington Avenue

New York, New York 10022

Attn: Richard W. Porter, Consultant, Aerospace Science and Technology

Hittman Associates, Inc. P.0. Box 2685

4715 East Wabash Avenue

Baltimore, Maryland, 21215

Deputy I. G. For Insp. and Safety, USAF, Kirtland Air Force Base,

New Mexico 87117

Attn: Col. D. C. Jameson (AFINSR)
Institute for Defense Analyses 400 Army Navy Drive

Arlington, Virginia 22200

Attn: Richard Briceland

Lockheed Missiles and Space Co. P.0. Box 504

Sunnyvale, California

Attn: H. H. Greenfield, Manager Nuclear Power Deve1opment

R. F. Hausman

(Dept. 30-63)

Cryogenic and Nuclear

Stage Programs (1)

Harold F. Plank (1)

Los Alamos Scientific Laboratory P.O. Box 1663

Los Alamos, New Mexico 87544

Attn: C. F. Metz, CMB-1 (1)

F. W. Schonfeld, CMF-5

Dr. L. D. P. King (1)

Dr. Wright Langham

Lovelace Foundation for Medical

Education and Research

5200 Gibson Blvd., S.E.

Albuquerque, New Mexico

Attn: Dr. C. S. White,

President-Director

Martin Company

Nuclear Programs

Middle River, Maryland 21203

Attn: D. G. Harvey, Mail No. 801

Minnesota Mining and

Manufacturing Co.

2501 Hudson Rd., Maplewood

St. Pau1, Minnesota 55119

Attn: J. P. Ryan, TCAAP 675

Nuclear Products Dept.

Monsanto Research Corporation

Mound Laboratory

P.O. Box 32

Miamisburg, Ohio 45342

Attn: G. R. Grove

Administrator

National Aeronautics and

Space Administration

Washington, D.C. 20545

Attn: T. B. Kerr (RNS)

National Aeronautics and

Space Administration

Ames Research Center

Moffet Field, California

Attn: Glenn Goodwin 
DISTRIBUTION (cont):

National Aeronautics and

Space Administration

Goddard Space Flight Center

Glenn Dale Road

Greenbe1t, Maryland 20771

Attn: A. W. Fihe1ly, Nimbus Project

Nationa1 Aeronautics and

Space Administration

Lewis Research Center

21000 Brookpark Road

Cleveland, Ohio 44135

Attn: Library

National Aeronautics and

Space Administration

Manned Spacecraft Center

Houston, Texas 77058

Attn: Technical Information

Dissemination Branch

(Code BM6)

National Aeronautics and Space (2)

Administration, Scientific and

Tech. Info. Facility, P.O. Box 33

College Park, Maryland 20740

Attn: Acquisitions Branch $(\mathrm{S}-\mathrm{AK} / \mathrm{DL})$

Nuclear Materials and Equipment Co., Apo11o, Pennsylvania 15613

Nuclear Utility Services Corp. Environmental Safeguards Div.

Suite 1100

1730 M Street, N.W.

Washington, D.C. 20036

Attn: M. S. Goldman,

Vice President

Phillips Petroleum Company

NRTS Technical Library

P.0. Box 2067

Idaho Falls, Idaho 83401

Radio Corporation of America

Astro Electronics Division

P.O. Box 800

Princeton, New Jersey 08540

Attn: S. H. Winkler

LDR. Adv. Power

Director, USAF Project Rand

Via Air Force Liaison Office

The Rand Corporation

1700 Main Street

Santa Monica, California 90406

Attn: Library
Space Nuclear Propulsion Office

Lewis Research Center

21000 Brookpark Road

Cleveland, Ohio 44135

Attn: L. Nichols

TRW Systems

P.0. Box 287

Redondo Beach, California 90278

Attn: Dr. Donald Jortner

U.S. Nava1 Radiologica1

Defense Lab.

Commanding officer and Director

San Francisco, California 94135

Attn: P. E. Zigman

Union Carbide Corporation

Nuclear Division

P.O. Box X

Oak Ridge, Tennessee 37831

Attn: R. A. Robinson, Isotope Dev. Ctr.

R. B. Fish, Hea1th

Physics Div. (1)

Union Carbide Research Institute P.0. Box 278

Tarrytown, New York

Attn: Joseph Agresta Space Sciences Group

University of California

Lawrence Radiation Laboratory

P.0. Box 808

Livermore, California 94551

Attn: Dr. James Hadley Chief, R. Division

Technical Information Division (1)

Westinghouse Electric Company

Astronuclear Laboratory

P.0. Box 10864

Pittsburg 30, Pennsylvania

Attn: Joanne M. Bridges, Supervisor, Flight

Safety Analysis Group

P. M. Ordin

Space Nuclear Propulsion Office

Lewis Research Center

21000 Brookpark Road

Cleveland, Ohio 44135

Harry Bechto1

Aberdeen Proving Ground

D\&PS

Aberdeen, Maryland 
DISTRIBUTION (Cont):

J. A. Hornbeck, 1

R. W. Henderson, 1000

L. A. Hopkins, 1300

J. H. Findlay, 1400

S. A. Moore, 1540

R. S. Claassen, 5100

T. B. Cook, 5200

R. G. C1em, 5630

W. T. Moffat, 7220

H. E. Viney, 7250

L. E. Lamkin, 7300

G. A. Fowler, 9000

D. B. Shuster, 9200

V. E. Blake, 9310

S. L. Jeffers, 9312

R. J. Everett, 9315

J. D. Appel, 9319 (ANSIC)

R. C. Maydew, 9320

A. J. Clark, 9330

J. L. Tischhauser, 9420

B. S. Biggs, 8000

B. F. Hefley, 8232

B. R. Allen, 3421

W. K. Cox, 3428-1, B1dg. 802

C. H. Sproul, 3415-3 (10)

J. Shunny, 3412

R. S. Gillespie, 3413

For: DTIE (3)

H. F. Carroll (1) 